\title{
Druze Women and Gender in Druze Society: A Systematic Literature Review
}

\author{
Rami Zeedan*(D) and Miles Luce (D) \\ Jewish Studies Program, The University of Kansas, Lawrence, KS 66045, USA; miles.luce@ku.edu \\ * Correspondence: rzeedan@ku.edu
}

Citation: Zeedan, Rami, and Miles Luce. 2021. Druze Women and Gender in Druze Society: A Systematic Literature Review. Religions 12: 1111. https://doi.org/ $10.3390 /$ rel12121111

Academic Editor: Kimberly Rios

Received: 26 September 2021 Accepted: 9 December 2021 Published: 17 December 2021

Publisher's Note: MDPI stays neutral with regard to jurisdictional claims in published maps and institutional affiliations.

Copyright: (c) 2021 by the authors. Licensee MDPI, Basel, Switzerland. This article is an open access article distributed under the terms and conditions of the Creative Commons Attribution (CC BY) license (https:// creativecommons.org/licenses/by/ $4.0 /)$.

\begin{abstract}
This systematic literature review on Druze women and gender in Druze society reviews central conceptual themes from existing publications to chart future research trajectories. Using a meta-ethnographic methodology, this literature review covers Druze women's experience of gendered realities in higher education, economic participation, marriage, family life, and health. Our systematic literature review allows us to offer two propositions on existing published knowledge pertaining to Druze women and gender in Druze society. First, we propose that scholarship on Druze women and gender in Druze society constructs Druze women's experience of gender as not only discursive but material. We incorporate the process of women's relationship with prohibitive mechanisms of gendered space and men's experience of masculinist subjectification into an existing term: the spatialization of everyday life. Second, quantitative analysis reveals a disparity in publications between Israel and other countries such as Lebanon, Syria, and Jordan. We propose that this disparity relates to the concept of "Druze particularism" while emphasizing their difference vis-à-vis Islamic religion and Arab culture. We suggest that future research thoroughly covers other national contexts and inter-national comparisons of Syria, Lebanon, Jordan, and the diaspora, especially in education, economy, and health. Future research trajectories could include examining contemporary sociolegal research on the legal regime that governs family life, research on Druze men from an explicitly feminist perspective, or publications of influential Druze women.
\end{abstract}

Keywords: women; gender; feminism; Druze; Muslim; Israel; Lebanon; Syria; Arab

\section{Introduction}

The Druze emerged from Isma'ili Islam at the beginning of the 11th Century Fatimid Egypt (Halabi 2013, p. 16). Nowadays, most Druze communities are located in the Middle East (Obeid 2006, p. 9). Estimates of the number of Druze vary and include above 1 million people. The largest communities are in Syria and Lebanon, with about $6 \%$ and $7 \%$ of the population, respectively. Smaller communities are in Israel and Jordan, with about $1 \%$ of the population of both countries (Swayd 2009, p. xxxiii). Other smaller communities of the Druze can be found in some European countries, Northern America, Latin America, and Australia, among other countries (Swayd 2009, p. 49).

Druze scripture holds egalitarian regard for men and women in spheres like marriage, divorce, and inheritance (Halabi 2014, pp. 428-29). Some authors have used this fact to differentiate the Druze from other sects of Islam, specifically in strictures regarding the observation of monogamy and prohibition of polygamy (Obeid 2006, p. 183). Others used these same specificities to differentiate the Druze from Islam altogether (Layish 1979). In practice, patriarchy persists in Druze society, with women suffering gendered inequalities in various ways (Azzam 2007, pp. 42-43). Gender has a complex and intricate operation within Druze society, making the question much more complicated than proclaiming it egalitarian or its opposite.

This systematic literature review intends to initiate a cross-disciplinary dialogue between Druze Studies and studies of gender and sexuality. Studying gender in Druze 
society provides a more holistic anthropological and sociological account of the Druze. Additionally, this literature review identifies neglected areas in the current literature on Druze women and gender in Druze society, such as studies by country and feminist perspectives on Druze men. Furthermore, the systematic nature of this literature review works to generate and test certain propositions about gender in the context of the body of literature in question. The first proposition claims that gender in Druze society operates not only discursively but materially. The second proposition asserts that the disparity in publications on Druze women and gender in Druze society between Israel and other countries relates to the concept of "Druze particularism" while emphasizing their difference vis-à-vis Islamic religion and Arab culture.

This article is important since it aims at drawing attention to the negligence of research on marginalized women. Its importance is even more noticeable since Muslim women tend to be marginalized in feminist scholarship. More specifically, the subject of our investigation, Druze women, consists of a double-marginalized group in society. Focusing this study on Druze women while situating them within the social structure in their respective states helps further diversify the field with such a marginalized group. Generating this systematic review and providing a trajectory for future research aims to encourage more research on the topic to fill the existing gaps.

The article includes the following sections: Methods, General Findings, State of the Theories and Research, Discussion and Conclusions, and Future Trajectories.

\section{Method}

First, we searched for scholarly publications on the topic that were available in English. The search focused mainly on books and articles, using Google Scholar and other academic search engines. We used the following keywords: Druze, Women, Gender, Feminism, Israel, Lebanon, Syria, and Jordan. This resulted in a list of more than 11,300 articles, books, and book chapters. Eliminating duplications and "gray literature" on the topic resulted in cutting the list by half. Next, we examined the abstract of the publications in search of those pieces directly focusing on the Druze. The final step was reading the full articles and making the determination to include only publications that fit the topic. This resulted in 56 entries that directly focused on women and gender among the Druze or used the Druze in a comparative study. In the second step, we prepared an annotated bibliography on each of these entries, including the main findings and the research method used. We described possible correspondence with the theories from other entries.

After these initial steps, the third step was to create a systematic review of the topic by grouping the entries into six groups of interest: "Gender and Feminism", "Education", "Marriage and Family", "Economy", "Health", and "Miscellaneous". This was done by collecting data on the published entries that included the following information: year of publication, country of focus, country of affiliation of the primary author, type of publication, discipline, the research method used, and the literature's significant contributions to the field.

We based our method on previous systematic literature review methods detailed by Xiao and Watson (2019). Specifically, we drew upon the method of meta-ethnography. Meta-ethnographies review a source's second-order constructs—for example, "hybridity," constructed from first-order accounts by participants or statistical analysis on surveys or questionnaires (Weiner-Levy 2008a). Then, we synthesized them into third-order constructs that represent new findings, conclusions, and trajectories for the literature in question (Xiao and Watson 2019, pp. 100-1).

\section{Findings}

\subsection{General Findings}

Table A1 presents the list of the 56 chosen entries that focused on women and gender in Druze society (see Appendix A). We found only one book on the subject, 13 book chapters, and 36 scholarly articles of the chosen entries. We also included two Ph.D. dissertations, one 
MA thesis, and three movies relevant to our review. Thirty-six out of the 56 entries focus directly on the Druze, while the remaining 20 entries examined the Druze case compared to others. The majority of entries emerge from gender studies and sociology, among other disciplines, numbering at 15 for the former and 13 for the latter. The additional fields include economy (7), anthropology (5), health, medicine, and biology (5), education (5), law (5), and other (history, political science, and psychology; (5)). The variety of the disciplines reflected on the various methods that authors employed. Twenty of the entries were based on interviews, of which 15 utilized a small sample size. The second most popular method, used by 16 studies, was a textual analysis of primary sources and similar methods. The third method, statistical analysis, was conducted by 14 of the studies by using large sample sizes. Additionally, two publications used mixed methods.

We divided the publications into groups by the decade of publication. From the 1970s through the end of the 1990s, there were only nine publications on the topic. However, in the early 2000s, an additional 13 publications in that one decade signaled that women and gender in Druze society were becoming more noticeable to researchers. This phenomenon continues into the 2010s, with an additional 32 publications on the topic. We anticipate this trend will continue in the 2020s.

Figure 1 shows the distribution of these publications over the decades per country of focus. It shows that out of the total 56 , about $70 \%$ focused on Israel. The focus on the Druze in Israel begins with a few publications in the 1970s-1990s before becoming a more established trend in the last two decades. After Israel, Lebanon emerged as the second country of focus. Conversely, there were very few publications of global nature. Furthermore, no publications reviewed focused on Druze women in Jordan or the Druze diaspora. Although the Druze in Syria are the largest single community in one country, we found little research interest on them in this topic.

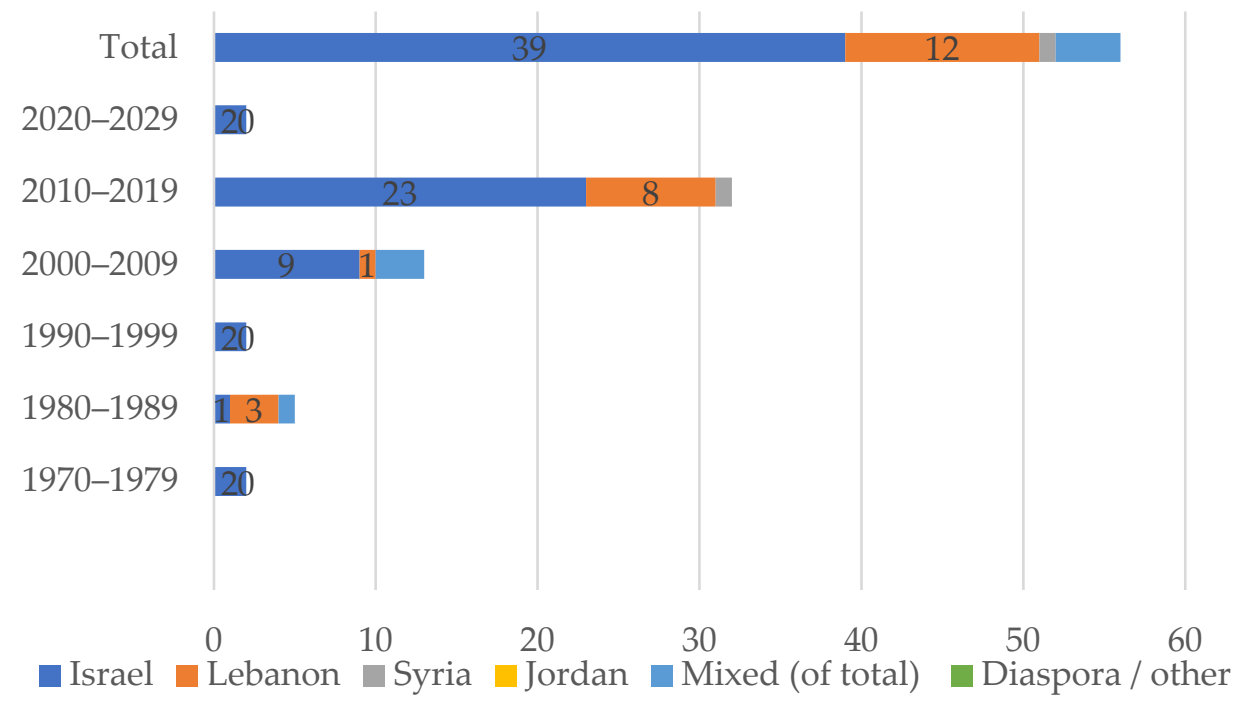

Figure 1. Country of focus.

When we examined the institution and country of affiliation of the publications' authors, we found a correlation with the country of focus. As shown in Figure 2, most authors were affiliated with an Israeli institution, namely 35 out of 56 . The trend followed the same pattern as the country of focus. The trend is more evident in the last two decades; most authors affiliated with Israeli academic institutions published research on the Druze in Israel. Only six publications were on the Israeli Druze but published by an author not affiliated with an Israeli institution. However, this is not the case for Lebanon. Only half of the published scholarship on the Druze in Lebanon was by authors affiliated with Lebanese academic institutions. The other half were written by authors affiliated with other countries such as the US and Canada, probably resulting from larger Lebanese-Druze 
diaspora communities in these countries. This is an interesting phenomenon that deserves its own examination in future research.

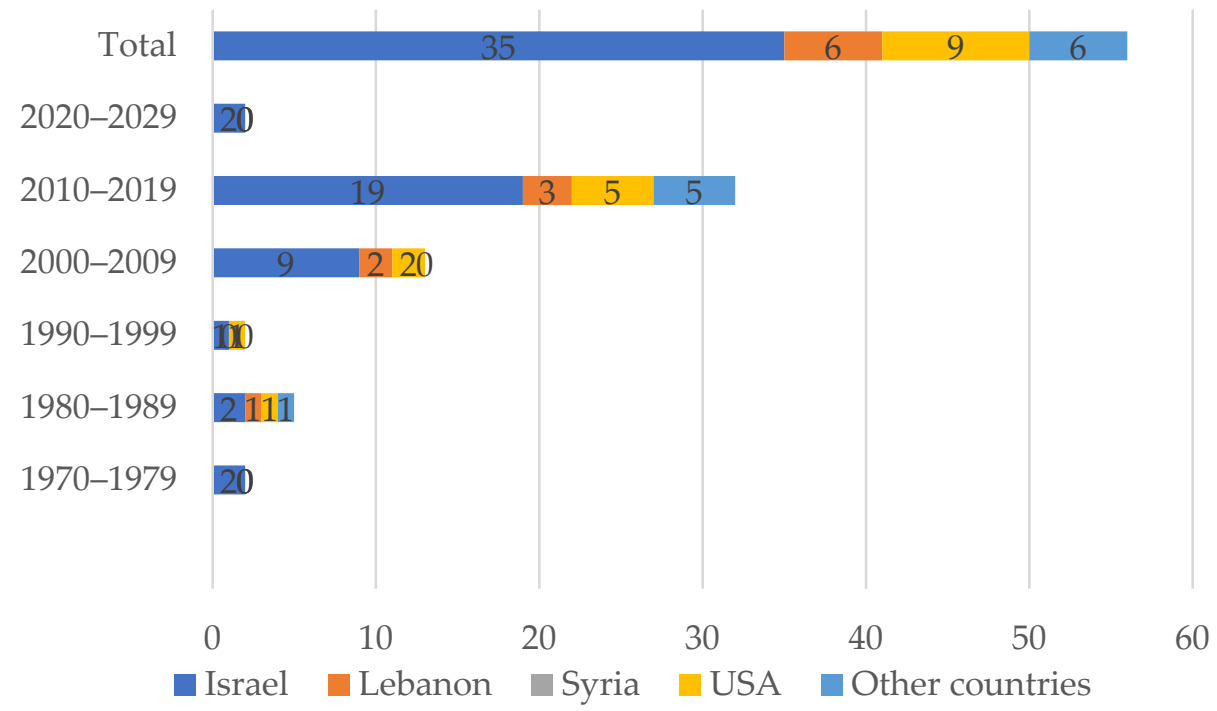

Figure 2. Country of affiliation of the primary author at the time of publication.

\subsection{State of the Theories and Research}

In the following section, we offer an overview of the state of the research on the topic. This is divided into sections. The "Gender and Feminism" section details Druze women's relationship with politics, sexuality, patriarchy, and sexual violence while introducing critiques of a western feminist framework's application to Druze society and Druze women's experience. The "Education" section features research on Israeli Druze women's experiences of attending higher education, how secondary and higher education affects Israeli Druze subjectivity, as well as the university as a site of power. The "Marriage and Family" section represents a wide variety of research and films ranging from legal, anthropological, to sociological views on marriage, divorce, widowhood, and adolescent experience within the Druze family unit. The "Economic" section interprets statistical data revealing intercommunal gendered economic inequality and intercommunal economic inequalities that reflect the regime of "Druze particularism". "Health" showcases religious, medical, and psychological views on the concept of "health" and self-esteem for Druze women, domestic violence, and sex preferences for obstetricians and gynecologists. The final part was miscellaneous, which included topics with less coverage by the existing literature. This included "Druze Men" and "Important Druze Women".

\subsubsection{Gender and Feminism}

Researching Druze women's relation to conceptions of gender and feminism represents an important area of study for scholars avoiding the universalization of western feminism as a salve for gender oppression across diverse geographic contexts.

The most comprehensive portrait of gender in Lebanese Druze society is provided by Azzam (2007). Section 1 details the pitfalls of both Druze and non-Druze accounts of the religion and culture regarding gender. Azzam identifies a trend in publications that overstates the egalitarian nature of Druze society, providing evidence to the contrary in the context of education, interpersonal violence, and marital abuses. Additionally, the chapter concludes by emphasizing Druze narratives that detail some of the insidious manifestations of gender, a format similar to how Raufman (2018) describes the functionality of fairytales in highlighting instances of sexual violence in an uncensored manner. The chapter also problematizes Alamuddin and Starr's (1980) understating the patriarchal control exerted over women within the 'uqqāl. ${ }^{1}$ Azzam's Section 2 presents a comparative textual analysis of gender equality in the Qur'an and Druze scriptures. It recites passages of the Druze 
text that grant women equal status as men in various fields such as religion, marriage, and economics. ${ }^{2}$ Azzam concludes Section 2 by proposing that patriarchal aspects of the Druze community occurred from the influence of taqiyya, ${ }^{3}$ a claim the author explores in Sections 3 and 4 .

In Section 5, Azzam discusses surveys of Lebanese Jismani Druze. Two hundred forty-nine Druze women and 256 Druze men reported various topics, including opinions toward the mashaeikh, knowledge on women's rights in marriage and divorce, and attitudes towards mahr (dowry) women's education. The chapter also features data tables and excerpts from interviews that capture the nuances of each topic and its change over time. Chapter 6 uses narrative accounts of Druze women's experiences to elaborate on education, men's unilateral divorce (talaq, see Layish 1982), women's divorce rights, men's extramarital affairs, domestic violence, honor killings, employment, and inheritance. The chapter's extrapolation on education and employment remains one of the only engagements of these topics in a Lebanese context.

Barakat et al. (2018) and Daoud (2006) investigate the Druze women's relations to politics within Druze villages, everyday methods of subverting patriarchal control, the public/private dichotomy, and the Knesset. Barakat et al. illustrate the relationship between the hamula family structure and Druze women's access to personal autonomy in mobility, education, and employment. ${ }^{4}$ Relying on 60 interviews of Druze women, 30 employed and 30 unemployed, the article conducts an intersectional analysis to reveal how the dynamic between religious-social status and gender shape Druze women's lives. The article deviates from the western feminist proposition of dismantling the "public/private dichotomy" insofar as it argues that Druze society intertwines public and private cemented by institutionalized patriarchy. Daoud (2006) historicizes Palestinian participation in Israeli electoral politics. The article primarily centers on the experience of Husniyya Jabara, who was the first Muslim woman elected as a member of the Knesset (MK) in 1999. Although brief, the article features the insight of two former Druze male MKs, Ayyub Kara and Salih Tarif, who speak of the barriers that Druze women face in political participation. Similar research by Raufman (2018) and Blumen and Tzafrir (2011) documents the physical restrictions like driving, travel, and supervision that bar, or limit, Druze women from various activities like higher education and dating life.

Another aspect of women's roles and religiosity in Druze society is discussed from an anthropological approach by Radwan (2016) and Schnabel et al. (2018). Radwan (2016, chp. 4) conducts a robust literature review of anthropological publications on the Druze, including topics of Druze marginalization in the Middle East; assimilation, transnational identity, and exogenous marriage; women's gender roles in Druze society; Druze politics and statism; reincarnation as a centripetal force of community cohesion; the question of secrecy and the sheikhs as keepers of secrets; identity, heritage, and Druze particularism; Druze relationship to land and geography; and Druze diasporic communities. Radwan then argues against reductive analyses of heritage by social scientists of the Druze, advocating acknowledging heritage as a "process of meaning making" (Radwan 2016, p. 148). Considering the extensive scope of this literature review, Radwan briefly mentions Druze women's experience in Lebanon but lacks elaboration and citations, pointing to the unfortunate lack of literature published on this question. Schnabel et al. (2018) interviewed a total sample size of 5601 Israelis-with 3789 Jews, 871 Muslims, 468 Christians, and 439 Druze-to account for gender gaps in religiosity. The data finds a gender gap in religiosity where at least ten percent more women than men attend services weekly, pray daily, and greatly value religion. The article identifies essentialism in the existing literature on gender gaps in religion, where the prevalence of women's expanded role in religion almost always exceeds that of men. Though the study primarily concerns Jewish Israelis, it provides a quintessential set of generalizable data on Druze women's role in religious life.

Raufman (2018) analyzes how Druze oral tradition allows women to share uncensored tellings of experiences of domestic sexual violence. The author relates the symbols and motifs of "The Maiden without Hands" fairy tale in the Druze oral tradition to the lived 
reality of Druze women who experience rape by men inside and outside their families. The article relies on narratives of family honor killings to demonstrate that Druze women experience "social disability" when they appear to deviate from the sexual values imposed upon them, either willingly or coercively (Raufman 2018, p. 272). The article concludes that the persistence of the "Maiden" fairy tale-while contributing to patriarchy by affixing no blame to the rapist-allows an uncensored reflection of Druze women's experience.

The sexual governance of male relatives detailed by Raufman (2018) parallels the findings of Barakat (2021), who tracks the subversive strategies of Druze women under patriarchy. The research employs interviews between 2010-2012 of 60 thirty-to-fifty-yearold Druze women and narratives from the mid-1980s until 2010. The first strategy that Barakat details, concealment (istighāba), enables Druze women to explore their friendships and sexuality outside of compulsory male supervision. Barakat also emphasizes the prohibitive mechanism of gossip, documented by Weiner-Levy and Blumen and Tzafrir (2011). Barakat discusses the second strategy, negotiation, in the context of women's right to drive and excommunication, also addressed by Weiner-Levy. The article's discussion of a mahram ${ }^{5}$ parallels the spatiality of gender in Blumen and Tzafrir (2011). The manuscript's recency and consolidations of Druze women's everyday resistances from various articles position it as essential research for feminist Druze Studies.

Dayan (2019) and Halabi (2014) examine Druze attitudes on women's "sexual honor." Dayan (2019) compares rates of female honor killings among Israeli Arab communities. The article employs media surveillance to document instances of femicide between 20102015 , intending to provide empirical data confirming hypotheses regarding honor killings correlation with processes of rapid modernization and economic status. Although the article records 58 cases of honor killings, the distribution among Christians, Muslims, and Druze, points to the validity of investigating the sociological factors behind honor killings. Five instances of honor killings within the Druze community were recorded. The variability of Druze concepts of honor documented by Halabi (2014) complements Dayan (2019)'s findings, both of which critique the culturalist account of honor killings that attribute femicide entirely to Orientalist and homogenizing accounts of Arab cultures. Halabi (2014) analyzes interviews of 25 male and 25 female Druze university students conducted in 2001-2002 over women owning driver's licenses, sexual double standards, and intermarriage. The participants expressed a range of perspectives, varying from liberal to conservative visions for Druze women's role in society. Although various viewpoints were recorded, Druze women's sexual "honor" was almost unanimously defended by participants. Halabi offers multiple possible explanations for Druze women advocating for the restriction of their sexuality, given the double standard of Druze men's engagement in sexual relationships outside of the community. The article concludes by noting how Druze women must bargain with patriarchal norms to pursue their self-interests, noting gains in education, examined in detail by Weiner-Levy (2011) and Blumen and Tzafrir (2011). At the core of the article, Halabi attempts to articulate a middle ground between Druze patriarchy and western feminism critiques.

\subsubsection{Education}

Education represents an arena of power where Druze women negotiate with patriarchy and national identity. This is especially relevant to Israel, where research on Druze education is unique and well documented compared to other countries, especially concerning gender. Weiner-Levy's extensive study of the topic produced a few significant articles. The research highlights Druze women's negotiation experiences with parents and patriarchy, hybrid identity, and feelings of alienation.

Weiner-Levy's (2008a) article on power dynamics between the author's positionality as an Israeli-Jewish researcher and the author's Druze subjects extols the importance of analyzing gender, race, and class within the process of anthropological research itself. The author draws upon 34 personal interviews with Druze women who were among the first in their communities to attend Israeli universities. Avoiding the universalization of the 
researcher's position of power over the subject, Weiner-Levy examines it contextually by noting that both positions experience constant flux according to the feelings exchanged in the research and the identity of "twoness" expressed by the Druze women interviewed. Weiner-Levy (2008b) tracks Druze women's changes in personal identity after attending higher educational institutions. Employing a similar methodology to her article mentioned above, she interprets the women's subjective position on the transition between two societies with conflicting values using a narrative methodology. According to the interviews, Druze women exposed to western values in higher education experienced feelings of "hybridity" on returning to their villages where social sanctions policed their overt identity. Yet, they held inner thoughts and opinions characteristic of their time outside of traditional Druze culture. Weiner-Levy notes that western theoretical models of identity fail to contemplate the hybrid experience of Druze women. The same phenomena of Druze women's ideological alienation after exposure to western values is also detailed by Weiner-Levy (2009). This article similarly illuminates the alienating effects of Druze women returning to their villages from higher educational institutions. Weiner-Levy locates social gossip and uneducated Druze women as conduits for enforcing Druze society's patriarchal norms against returning educated women. Educated Druze women betray standards of ideal femininity, consequentially subjecting unmarried, educated Druze women to greater control by their male family members. Additionally, Weiner-Levy notes male interpretation of Druze religious law bars women from greater access to equality, discussed in a Lebanese context by Bennett (1999, chp. 5).

More specific to male control over Druze women, Weiner-Levy (2011) further analyzes the relationship between Druze women and their fathers in the context of subverting gender roles, drawing from the same pool of interviews. Due to their clan status, men from minor hamulas face fewer social consequences to enable their daughters to attend higher educational institutions. The article complicates a straightforward interpretation of patriarchy as "women vs. men" by locating fathers as a critical figure in Druze women's empowerment.

While Weiner-Levy's research focuses on Druze women and education in the context of social structure, another pair of scholars, Blumen and Tzafrir (2011), theorize Druze women's university attendance through spatial terms, where the act of commuting metaphorizes traveling between two covert and covertly overt identities with differing levels of autonomy. The two researchers interviewed 22 young Druze women commuting to city universities. The interviews express the Druze women's hybrid identity epitomized by the interplay of urban life contrasting with the traditional setting of their home. They theorize the spatial and temporal restrictions imposed on Druze women by geography within a gender analysis. The article's hemes of negotiation with patriarchy and the regulatory mechanism of social gossip represent a continuity of Druze women's experience in pursuing higher education.

Another perspective of Druze women in education focuses on the effect on the social self-identification of Druze women. Blumen and Halevi (2005) and Geiger (2013) detail Druze women's unique positionality within the university. It is defined by a simultaneous encounter with the dominant yet unattainable Jewish culture in Israel and exclusion from Arab identity formalized by a history of Druze particularism.

Blumen and Halevi (2005) investigate the interplay between gender and nationality in the perspectives of women who graduated from Haifa University's Women's Studies program in 2000-2003. Of the 12 Jewish and 11 Palestinian interviewees, four were Druze women. The article reveals how the classroom allows women to place their collective feminine identity above consideration of Israeli-Palestinian national identities. Consequentially, the Jewish women interviewed exhibited egalitarian gender politics without much care towards their Palestinian peers. Some even profess a paradoxical view of retaining hierarchies in terms of nationality but not gender. Unfortunately, only one Druze woman's perspective, Rula, held significant weight in the article. Rula notes that others view her with a sense of alienation from other Arab cultures via Druze particularism. Yet, 
she professes how the Israeli government only treats the Druze opportunistically. Rula's response parallels Weiner-Levy (2008b)'s research on university-educated Druze women's negotiation with patriarchy as well as feelings of hybridity and alienation from other uneducated Druze women. Rula's perspective further complicates the dynamics between national, civic, and gender identity discussed in the article, yet her contributions were unfortunately not discussed at length.

Geiger (2013) interviews 22 Muslim, 12 Druze, and 8 Christian women-most interviewees report living in ethnically homogenous villages-attending westernized Israeli universities. The women describe their process of acculturation regarding a variety of topics within higher education. Primarily, the women described linguistic barriers with the transition to a Hebrew-speaking educational space, the relationality of their professors, and interactions with Jewish students. The Druze women interviewed noted a unique feeling of alienation: a distance from Jewishness and a rejection from Muslim circles because of the perception of Druze collaboration with the Israeli state. The regionalized universities permitted Arab women to pursue higher education despite their village's geographic location restrictions. The multicultural environment within the universities altered the perspectives of the women interviewed regarding other ethnic groups.

Other scholars further develop the idea of Druze particularism while contextualizing its implementation to secondary Druze schooling as assimilation of Druze students into the Israeli body politic. Overall, the Israeli educational system produces gendered realities for Druze men and women: one defined by military service and the other funneled into certain "acceptable" types of employment. Saba-Sa'di and Sa'di (2017) expose the role education plays in fostering Druze particularism. The article cites interviews from three long-employed Druze women from a sample of 35 interviews documenting female Arab teachers' experiences while analyzing primary sources from The Arab Affairs' Committee to articulate the history of Druze particularism. The article then identifies the inner workings of Druze schools from a Foucauldian perspective: a subjectification of Druze adolescents to the Israeli state. While the article does not begin from an explicitly feminist perspective, it maintains a framework handy for feminist analysis given its attention to how socializing factors like gendered militarism drive Druze men to conscription.

\subsubsection{Marriage and Family}

Literature on Druze marriage and family provides anthropological insights that contextualize Druze women's lived experiences. These experiences differ between countries and are contextually affected by the political relations between these countries. This section will survey the situation of the Druze in Lebanon, then in Syria, and Israel, including the unique status of the Golan Heights. Interestingly, this section is the most outdated. The majority of articles we reviewed and were published before 1999 are included in this section.

As for the Lebanese experience, several scholars provide sociological, anthropological, legal, and statistical analyses of Druze marriage practices in Lebanon. Alamuddin and Starr (1980, chp. 4) observe how giving mahr reflects specific social values in Lebanese Druze marriage contracts. The chapter tracks contracts signed by Druze courts from 1931 through 1974 and relies on multiple interviews with sheikhs and judges. The chapter's findings reveal a marital emphasis on virginity, social stratification, and political endogamy signified by disparate amounts of mahr given, acting as insurance to deter divorce. Beaini (1989, chp. 4) details a description of mahr's use by the Lebanese Druze. It records the 14-step process of marriage for the Lebanese Druze living in the Shouf Mountains. The dissertation utilizes participant observation and questionnaires/personal interviews to collect data used to paint a detailed picture of Druze marriage practices. The chapter provides a comprehensive view of the dimensions of Druze marriage, especially useful considering its attendance to a Lebanese Druze perspective.

Fournier et al. (2018) document women of multiple religions' lived marriage experiences under existing legal and religious strictures. The article injects a feminist perspective 
into the Lebanese debate between religious and secular marriage. Although the author cites Druze women's interviews sparsely, it begins from a clear feminist perspective and displaces the prevalence of Israeli-centered articles cited in this literature review. The article follows Barakat et al. (2018) in noting the complexity of the public/private sphere dynamic regarding Lebanese marriages, rendering a western feminist perspective insufficient. Tarabey (2013, chp. 5) also contributed to the discussion on the Druze in Lebanon while focusing on divorce. The author conducted a comparative analysis of Lebanese Druze marriage and divorce contracts between 1970-2003, testing whether various factors including age, location, and relatedness contribute to divorce. The chapter notes the limited nature of the comparative analysis, explaining how the lack of a national census in Lebanon complicates statistical analysis.

Di Ricco (2012) describes a historical account of Lebanese Druze women's activism in personal status law. The article provides introductory information on Lebanese Druze law and the Lebanese legal system, essential for understanding more intricate delves into Druze law, like Layish's $(1978,1979,1982)$ research. The chapter historicizes the demands and activist work of prominent Lebanese Druze women, demystifying the "egalitarian" nature of Druze laws' pertinence to gender, a similar theme researched by Bennett (1999) in a Syrian context. The conclusion emphasizes the importance of the community sphere, rather than solely the national sphere, as an essential site for galvanizing legal reforms. The specificity of Lebanese legal "spheres" points to the importance of anthropological work in deconstructing the oft-universalized frameworks of western feminist perspectives, critiqued in the context of the public/private dyad by Barakat et al. (2018). However, Barakat et al.'s research remains limited to Israel, alluding to the importance of recognizing the hegemony of Israeli Druze perspectives within feminist analyses on the Druze.

Khoury and Wehbi (2016) present a theoretical framework for Lebanese women leaving abusive heterosexual relationships. Based on interviews with 24 women, the article presents three stages that initiate women leaving their abusive relationships while resisting social marginalization. The paper contributes to a body of research that divests from a victim/survivor dichotomy that would read women remaining in abusive relationships as passive and weak, opting for a feminist perspective that emphasizes the importance of women's stories rather than the categorization of their experience. Although the article features Suzanne, a Druze woman, it fails to acknowledge the specificities of the Druze community. Suzanne's expectation of equality between spouses contextualizes Bennett's (1999) analysis of the irreconcilability between promises of gender equality within marriage law and the unequal actualization of the law.

Another critical aspect of Druze marriage practice lies in its endogamous nature and the context of interfaith marriages, especially in Lebanon. Klat and Khudr (1986) used a sample of 750 mothers in the American University Hospital of Beirut maternity ward to track consanguineous marriages. Of the Druze, 37 of 40 marriages were endogamous. However, regarding consanguineous marriages, the data does not distinguish between religions. Charafeddine (2010) documents the statistical rates of Lebanese women marrying non-Lebanese men and interviews relaying the many hardships experienced under unequal citizenship laws that bar Lebanese women from transferring citizenship to their nonLebanese husbands. The study presents data on sparse Lebanese Druze marriages to non-Druze, reflecting the extensive practice of endogamous marriage within the Druze community.

The extent of research on Syria does not parallel the coverage of Lebanon in terms of literature on marriage practice. However, two important publications, Bennett (1999) and Kastrinou (2016) offer comprehensive anthropological accounts and critical analyses of Druze marriages in Syria. Bennett (1999, chp. 5) presents a general overview of the social and legal conventions of Syrian Druze marriage and family law. Bennett acknowledges the important fact that Druze society easily reaccepts intermarried sons when divorced compared to daughters. The author notes that upper-class Druze families can avoid marriage strictures, theorizing this double standard using philosophers Michel Foucault and Karl 
Marx. Bennett tracks the disciplining effects of social gossip contextualized to intermarriage, paralleling gossip's effects on Druze women pursuing higher education, described by Weiner-Levy (2011) as well as Blumen and Tzafrir (2011). The author depicts the intracommunity debate on intermarriage between two sides: one posits Druze purity over all else, and the other promotes pan-Arab unity, regardless of religion. Bennett recounts specific narratives of intermarried women, like Rana, whose brothers refuse her interfaith marriage, inheriting permissive authority from the passing of their parents. Concerning this particular phenomenon—sibling control—Raufman (2018) further describes Druze brothers regulating Druze women's sexuality, even in adulthood. Bennett weighs in on the aforementioned scholarly debate praising Druze religious law for gender egalitarianism compared to Sharia law-espoused primarily by Layish (1982) — by elucidating the difference between the law and the law's actualization; Bennett notes that Druze men can utilize divorce as a weapon against their wives. Furthermore, the author critiques western barometers for gender equality that ignores the lived experience of Druze women. Bennett then compares the status of civil marriage in Lebanon, Turkey, and Tunisia. Bennett's extensive fieldwork on the topic of Druze marriage, intermarriage, and divorce provide an excellent reference source for the "on the ground" materializations of Druze law in Syria while resisting the pitfalls of western feminism (Bennett 189).

Kastrinou (2016, chp. 4) juxtaposes a Syrian Druze woman, Zahra, and her mother, to demonstrate endogamous marriage's political and societal functions as both a gendered and classed phenomenon. Kastrinou weaves together an anthropological account of Druze marriages with a critical analysis relying on philosophers Judith Butler, Gilles Deleuze, and Martin Heidegger. The author critiques parallel research on gender in Druze and Arab society by Azzam (2007). While Weiner-Levy (2011) investigated the disciplined position of the Druze daughter, the chapter's conclusion expands on the role of the Druze mother who must choose "either her daughter or her society" (Kastrinou 2016, pp. 120-21). The chapter's intricate descriptions of Druze nuptial ceremonies and intensive theorizations make it inaccessible as an entry text. However, the recency, depth, and quality of Kastrinou's writing and analysis warrant a thorough engagement by any potential body of feminist research in Druze Studies, especially that it focuses on Syria.

The remaining articles reviewed in this section focus on the Druze in Israel while making a case for the different situation concerning the marriage and family status of the Druze in the Golan Heights. Despite Adwan's (2013) focus on interfaith marriage in Israel, the literature includes an extensive account of the endogamous marriages among the Druze in Israel. Layish (1982, chp. 4) utilizes data of 1972 Israeli marriage contracts provided by the Hebrew University of Jerusalem to track Druze endogamous and exogamous marriages by first-cousins, intra-clan, and rates by the village. Layish notes an increasing trend of Druze exogamous marriages and an increase in Muslim endogamous marriages in rural Israel. Layish heavily relies on legal jargon, making the read difficult as an entry text. Vardi-Saliternik et al. (2002) processed the degree of consanguineous marriages in a sample of 6001 interviewed women in Israeli maternity wards between 1990-1992. Of the sample, 1529 were Druze and Arab, with $47 \%$ of Druze marriages recorded as consanguineous. Although the article aims to prevent homozygosity increases, it provides data that reflects Druze human geography through patrilineality, endogamy, and location in rural areas. Additionally, it acknowledges that consanguineous marriage decreases among Druze women with higher levels of education and lower levels of religiosity.

Another important aspect of Druze marriage practice lies in age. Sabbah-Karkaby and Stier (2017) track the correlations between Druze women's marrying age and education. They employ the Israeli census from 1983, 1995, and 2008 from the Central Bureau of Statistics (CBS) to account for changes in marrying age for educated Israeli-Palestinian women. Fortunately, the article distinguishes between Muslims, Christians, and Druze, providing a set of processed data. However, the analysis does not consider the specificities of Druze women attending higher education or Druze marriage practices. The authors state that among Christian and Druze women, the age at marriage rose more substantially, 
from 22.5 to 24.7 for Christians and from 19.1 to 22.5 for Druze (comparison of the 1990s to 2012). Additionally, the chances of marrying declined with age for Muslims, Christians, and Druze.

Azzam (2007, chp. 4) provides a historical account of the formation of Druze Personal Status Law under the Lebanese recognition of the Druze as a sect. The chapter represents a continuity of Chapter 2 in detailing how egalitarian tenets from Druze scriptures manifest into current laws in terms of marriage and divorce. However, Azzam also notes the everyday use of mahr as a form of economic control over women. Still, Azzam argues that the institutionalization of Druze Personal Status Law has led to greater legal rights for women. Layish (1978) further discusses divorce and Layish (1979) discusses polygamy among the Druze in Israel. Layish (1978) details the permanence of Druze men's unilateral right to divorce Druze women (talaq). The article provides many instances where talaq was invoked but circumvented in various ways. The latter half of the article distinguishes between two schools of Druze legal thought: one emphasizing the sanctity of talaq at the moment of annunciation and one taking a much more flexible approach to wives' reinstatement after divorce. Layish (1979) features a legal history of Druze bans against polygamy. The article additionally historicizes instances of polygamy within the Druze community and the contemporary approaches of judges (qadis) to polygamy. The article shares analysis with Layish (1978) in noting how the more significant role of the Israeli government in Druze life has weakened the power of socio-religious sanctions against transgressors of Druze law.

This legal framework was put in place to help maintain the Israeli Druze family and social structures, as Oppenheimer (1980) describes. Oppenheimer mounts to an anthropological investigation of religious ideology's role in interacting with and preserving the Israeli Druze social network. Oppenheimer's approach parallels Kastrinou (2016) and Bennett (1999), who critically engage Druze marriage practices. The article provides valuable reference information about men's religious/social roles, men's supervision, and control of women, similarly articulated by Weiner-Levy, Raufman (2018), and Geiger (2013). Oppenheimer describes women's gender roles concerning reincarnation, neglected by the bulk of research on Druze women.

The Golan Heights has been occupied by Israel since the 1967 war, putting the Druze living there under a unique situation of being Syrian while living under the Israeli government (Kaufman 2004, p. 74). Riklis' (2004) film The Syrian Bride illustrates how in Golan Heights, Druze women, marriage, and family all connect to the contested occupation of the region by Israel. Protagonist Mona must renounce her Israeli citizenship to marry her distinguished Syrian husband. When Haifa University admits Mona's sister Amal, her husband pushes back against her attendance in the name of his masculinity, reflecting both the increasing level of Druze women attending higher education and the disciplining function of gossip in Druze villages recorded by Weiner-Levy (2011). Mona's brother Hattem faces their father's disapproval when he marries a Russian woman outside of the religion, demonstrating the catch-22 of intermarried Druze men who must choose between their spouses and their family. This use of characterization allegorically represents aspects of the Druze experience in Golan Heights while simultaneously interweaving each sub-plot to create a well-crafted narrative that displays the bridges between the personal and the political. Riklis fills the gap in the literature documented in this review by widening its scope to Israeli-Syrian relations and its effect on Druze women rather than merely Israel, Syria, or Lebanon in a vacuum. The importance here lies in the fact that the research surveyed in this review rarely exhibits a transnational character.

Harris (2013) analyzes three movies, including Riklis' film, within a critical analysis of gender and Israeli imperialism in the context of the occupied Golan Heights. The author compares the three films to demonstrate a cinematic shift away from the male gaze in films on the Israeli-Arab conflict and a nuanced depiction of women's experience within the conflict. Regarding The Syrian Bride, Harris argues that the insertion of Druze women as the vessel for recounting unfolding Israeli imperialism makes the film palatable to Israeli 
audiences by virtue of the Druze occupying an interstice position somewhere politically in-between the Palestinian and the Israeli. Harris comments on the theme of negotiation, an aspect of Druze women's experience navigating patriarchy recorded by Weiner-Levy (2011), Blumen and Tzafrir (2011), as well as Barakat (2021), noting that Amal's husband presents his masculinity as the opportunity cost to her attending university. Additionally, Amal must mediate with her father the attendance at the wedding of her exiled brother due to his marriage outside of the religion. Furthermore, the author extends the analysis to Amal's actress, Hiam Abbas, who is not a Druze. She similarly negotiates Palestinian women's representation in Israeli cinema while repeatedly cast in conflict with Makram Khoury, Amal's father in The Syrian Bride. Unfortunately, Harris comments on the other two movies reviewed-both without Druze women's presence-with greater length and nuance, allegorically reifying the notion of the "traditional" Druze woman as an "almost entirely silent" figure in her research itself. Harris even ironically acknowledges this trope as embodied by Amal's mother in The Syrian Bride (Harris 2013, p. 96). Research revealing Druze women's marginal existence in research, such as Pullum (2019), elucidates the urgency and importance of an explicitly feminist research project centering on Druze women and their gendered experience in Druze society.

Like Riklis' films, Adwan's (2013) film Arabani dramatizes Druze family dynamics centered on interfaith marriage and divorce. The film follows Yosef, a divorcee of an Israeli Jewish woman, returning to his Druze village. Yosef's children, unaccustomed to Druze culture and not considered Druze, create friction with the villages' sheikhs and incite some villagers to attempt to drive out Yosef's family. After trying to spark a romance with an ex-lover, causing Yosef's mother's exclusion from the prayer house, as well as receiving threats of arson, Yosef decides that his family must leave the village. Arabani shares The Syrian Bride's side-plot about Hattem, an intermarried Druze man, returning to the village, scorned by his parents, eventually receiving their love, then departing. Opening and closing with a shot of Yosef driving, Arabani conveys the literal and figurative mobility of the intermarried Druze man across geography and identity. This state of movement in Arabani and The Syrian Bride parallels the hybridity of Druze women who must commute to university, documented by Geiger (2013). As the sheikh recites to Yosef, the Druze take regulations quite seriously; Yosef's exile and scorn portray the great lengths the Druze take to preserve their religion and culture through the institution of marriage.

Another aspect of marital life examined in the Israeli context was that of Druze war widows' mental states, social life, and economic status. Katz (1990) surveyed 54 Druze war widows, comparing the formal benefits allotted to them with fundamental changes enacted in their life, compared to that of Jewish-Israeli war widows and civilian widows. Interviews were conducted in home settings. Participants were asked to fill out a Depression Adjectives Check List (DACL), report life changes after widowhood in eight different areas and describe their social lives within their own and husband's families. Katz (1990) found that while Druze law entitles war widows to a relatively large economic compensation than Israeli war widows, Druze women often face discouragement on behalf of their husband's family and cannot access the full extent of benefits entitled to them.

The research on Druze experience in Israel extends to family relations, Israeli Druze adolescents' decision-making and values, and their place in society. This is shown in the third movie in this review, by Mra'ana (2008), which displays a young woman's negotiation between her dreams of pageantry and Druze social norms. The documentary, Lady Kul El Arab, follows Duah, a Druze woman who entered as Angelina in an Israeli Pageant in 2007. Duah must negotiate her dreams of winning the pageant with pressure from the Druze community against her participation. Duah eventually withdraws from the contest after her attempted murder in the name of "family honor." Mra'ana's documentary showcases the hybrid identity of Druze women, caught between her desire for individualism and her traditional role within the Druze community, as extensively documented by Weiner-Levy. In the first half of the documentary, this conflict of hybridity unfolds through a strained relationship with her parents, a phenomenon detailed by Abbas et al. (2018). Regarding 
attempted murder, Raufman (2018) elaborates on the practice of honor killing within the Druze community in the context of incestual rape, while Dayan (2019) dispels pervading images about "honor" by analyzing honor killing that correlates it to sociological factors. Furthermore, Halabi (2014) features interviews from Druze adolescents that showcase various opinions regarding "honor".

Likewise, Abbas et al. (2018) investigate changing Druze adolescents' relationships with their parents given the increasing exposure of western values to the community. The article samples interviews from 12 Druze adolescents, six boys, and six girls, age 16-18. The interviews reflected that adolescents' desire for independence sparked conflict and that both boys and girls often had a close relationship with one parental figure over the other. The interviews show that while adolescents wished for greater autonomy in their personal lives, they still retained respect for their families. Furthermore, though not explicit, the interviews reveal a similar feeling of "hybridity" articulated by pioneering Druze women attending higher education in Weiner-Levy's research. Additionally, the article's inquiry parallels the acculturative research conducted by Geiger (2013) on IsraeliPalestinian women attending higher education, including Druze women.

Shamma and Asaqli (2020) surveyed 124 Druze and 119 Jewish 9-12th grade girls and boys regarding differences in adolescent decision-making by gender with a structured, in-depth questionnaire. The data reveals a shrinking gender gap in autonomy for Jewish adolescents and a slow liberalization of societal attitudes about Druze girls' autonomy in decision-making. These facts are reflected by the increasing levels of Druze women attending higher education as described by Weiner-Levy, Blumen and Tzafrir (2011) and Geiger (2013). The data confirms previous research noting the authority in decision-making granted to Druze boys and men due to the patriarchal and patrilineal structure of the Druze family.

\subsubsection{Economy}

Druze women's economic activity reflects their increasing access to education and benefits of Druze particularism compared to the economic reality for Muslim women. Within the Druze community, gaps in earnings persist between Druze men and women. Unfortunately, all published research surveyed in this section pertains to the Druze in Israel. No parallel studies were found for Druze women in Lebanon, Syria, Jordan, or the diaspora.

Khattab (2002), Offer and Sabah (2011), Kraus and Yonay $(2013,2016)$, and Yonay et al. (2014) track the contributions and changes over time to Druze women's participation in the formal Israeli labor force. Offer and Sabah (2011) document the change in married Arab Israeli women's labor-force participation over time, drawn from the 1983 and 1995 census conducted by the Israeli CBS. The article concludes that although married women have seen small gains in employment associated with access to greater levels of education, structural barriers in place make occupational opportunities increasingly difficult for any Arab Israeli woman. Offer and Sabah (2011) attribute textile factories placed near Druze villages as responsible for Druze women's jump in labor-force participation compared to Muslim women.

This is also noted by Khattab (2002), who grapples with disparate women's participation in the Israeli economy by ethnicity. The article uses Israel's 1995 census data to analyze theoretical models of culture's impact on women's and Arab participation in ethnic enclave economies. Khattab concludes by dispelling any notion that traditional cultural norms prevent women's access to the economy by virtue of exclusion from the public sphere. They explain Arab women's diminished participation in the Jewish-controlled economy by the incentives of ethnic enclave economies, the lack of economic opportunity in certain areas, and the role of the Israeli state in controlling those opportunities. Druze women enjoyed relatively significant opportunities from the Israeli government's policies of "Druze particularism". For example, Khattab notes that textile manufacturing jobs were 
placed at the outskirts of Druze villages, the sort of opportunity barred to their Muslim counterparts.

Yonay et al. (2014) offer another contribution to the question of culture's role in Druze and Muslim women's participation in the Israeli workforce. They use Israeli CBS statistics on localities with and without homogenous Muslim and Druze populations, tracking whether Christians interacted with Muslim and Druze women's workforce participation. The article denounces the Orientalist construction of Arab communities as inherently misogynistic and patriarchal, parallel to Khattab (2002). Yonay et al. acknowledge that their results reveal that religiously heterogeneous localities had higher Muslim and Druze women's workforce participation. However, the main factors affecting participationeducation and having young children-remained the same. To explain the gap, Yonay et al. track historical forces behind the Israeli states' favoring of Christians over Muslims, contributing to a significant socioeconomic advantage. In another article, Kraus and Yonay (2013) use CBS statistics to demystify the perceived lack of Palestinian women's contribution to the formal Israeli economy. The data differentiates by ethnicity and religion, providing a specific account of Druze women's economic participation. The study finds that Druze women's formal economic participation drastically increased from the mid-1990s to the late-2000s, with $75 \%$ of educated Druze women aged 25-52 employed as teachers, as demonstrated by the CBS' financial report from 2007-2009.

The data reflects the increasing phenomenon of Druze women attending higher education, as analyzed in research by Weiner-Levy, Blumen and Tzafrir (2011), and Geiger (2013). The study explains Palestinian women's over-representation in the formal economy by considering that women face less ethnic discrimination in the public sector. The study notes cultural constraints on Druze women's pursuit of nursing yet acknowledges the gradual deconstruction of the nursing taboo. Stier (2013) elucidates the greater economic power earned by Druze women in Israel since their access to higher education in the 1980s. The article examines the gradual increase in dual-income Israeli-Palestinian families from the 1980s-2010s. Additionally, the article conducts a multivariate analysis on data from the 1983 and 1995 Israeli Censuses and labor force surveys conducted from 2008-2011. Stier names the decrease in fertility rate and greater access to education as primary forces allowing Palestinian women greater participation in the Israeli labor force. They note that these facts ring especially true for Druze women in terms of education. The data collected tracks the definitive correlation between the level of education and likelihood of dual-income familial status for Druze women compared to Christian and Muslim women.

Further research conducted by Kraus and Yonay measures the earnings gaps between Druze women and different ethnic and religious groups. Kraus and Yonay (2016) conducted a multivariate analysis relying on 2008 Israeli Census Data to explain the gendered economic gaps between ethnic and religious groups. The article finds a substantial gender gap where Druze women only earn 59.5 percent of what Druze men earn (Kraus and Yonay 2016, pp. 191-92). They found that adding the variable of education for Druze men and women substantially changes the gender gap. Furthermore, they also note that Jewish and Druze women face fewer disadvantages in the public sector rather than the private sector, with the inverse being true for Muslim and Christian women. Kraus and Yonay (2018, chp. 8) compare Druze women's economic profile to Muslim women residing in the same localities. The article notes the increasing levels of Druze women's labor force participation, yet their Muslim counterparts face the reality of lesser economic opportunities. The chapter makes clear the wage gap for Druze women, which sits at a staggering 48 percent compared to the median salary of Druze men (Kraus and Yonay 2018, p. 193). The chapter's recency makes it an indispensable source for tracking recent economic changes occurring for Druze women.

\subsubsection{Health}

The primary literature on Druze women neglects discussions of health, a path of inquiry that reflects the consequences of patriarchal ideology, and Druze religiosity in 
approaches to dominant medical models. Again, as in the economy section, the health section privileges the case of the Druze in Israel. There is only one published research related to health that centers on Lebanon.

Amer-Alshiek et al. (2015) seek to introduce a culture-centered health framework, better prioritizing Druze women's conception of health in facets like the choice of obstetricians and gynecologists and approaches to modern medicine. They track Druze women's preferences of obstetricians' and gynecologists' gender according to 196 questionnaires distributed by five Israeli gynecologists. The questionnaires found that most Druze women preferred the same sex, citing reasons of comfort and embarrassment, consistent with responses across other Arab demographics. The article notes the increasing need to incorporate the specificities of patients' cultural perspectives similar to Yehya and Dutta's (2010) research on a health framework centering on Druze women. Yehya and Dutta (2010) study Lebanese Druze women's health from a culture-centered framework, displacing the supposed universality of the normative biomedical model. The article relies on 13 interviews with elderly Druze women and ten interviews with their daughters. The interviews highlight the role of God, labor, bodily sacredness, and modern medicine as invasive in elderly Druze women's conception of health. The authors' centering of Druze women attends to their marginalization in health and social science research discussions.

Goldblatt and Granot (2006) and Zaatut and Haj-Yahia (2016) research medical indicators of domestic violence against Druze women and the patriarchal ideology reverberated by uneducated women that place responsibility on the survivors of battery. The authors discovered a positive correlation between diminished health status, higher somatization levels, and the presence of physical abuse among Israeli Druze women. The article analyzes 100 questionnaires distributed at a medical clinic in a Druze village in Northern Israel. In line with Zaatut and Haj-Yahia (2016), the article's intentions seek to dismantle a patriarchal culture that disincentivizes women from reporting their experiences of abuse to physicians. Zaatut and Haj-Yahia (2016) track the correlation of patriarchal ideology and Palestinian women's opinions on wife-beating. The results rely on 701 self-administered questionnaires of Muslim, Christian, and Druze women. Using an intersectional analysis, the article isolates class status as a significant factor, where uneducated women were more likely to hold patriarchal beliefs about wife-beating. The article's findings on Druze women reveal that they hold wives responsible for battery more than Christian and Muslim women. Similar to Weiner-Levy (2011), the paper examines women's overlooked role in reverberating patriarchal beliefs.

Another literature review, Golan (2015), highlights factors behind Druze women's self-esteem and calls for more research on Druze conceptions of beauty and health. The article explores the societal, cultural, and religious context to Druze Women's self-esteem, drawing on a similar pool of research. The review neglects discussions of Druze women and marriage. Still, it highlights Druze women's beauty and health standards undercovered by the field, calling for more attention regarding this research trajectory. Overall, Golan (2015) contains an extensive bibliography for research on Druze women.

\subsubsection{Miscellaneous}

Under miscellaneous, we included other topics that did not generate as many publications as the previous sections: "Druze Men" and "Important Druze Women".

"Druze Men" focuses on Druze men's psychology as well as cultural and military participation. This section included the following entries: Pullum (2019), Sasson-Levy (2017), Saba-Sa'di and Sa'di (2017), as well as Florsheim and Gutmann (1992). Feminist perspectives have acknowledged the importance of including men in discussions of gender (Yefet 2015). However, there remains a critical gap in research on Druze men from an explicitly feminist perspective.

The "Important Druze Women" section focuses on publications directly dealing with influential Druze women in society. There are not many articles and books covering influential Druze women. For example, there are numerous books and articles about Kamal 
and Walid from the Lebanese leading family, Jumblatt. However, not on Nazira Jumblatt, a powerful Druze woman who led the Druze in Lebanon after her husband, Fouad. Nazira was the mother of Kamal and grandmother of Walid (Hazran 2015). Contrary to the other sections, this section mainly included Druze women in Lebanon, Syria, and the diaspora, but not in Israel. It includes published work by Obeid (2006), Halabi (2013), (Zuhur 2000), Cooke (2012), Prouty (2011), and Swayd (2009).

\section{Discussion and Conclusions}

In proposition one, we suggested that scholarship on Druze women and gender in Druze society constructs Druze women's experience of gender as not only discursive but material, especially in terms of spatiality. Discourse here refers to a conception of gender that might govern one's subjectivity or psychology. Gendered space emerges primarily as a system of prohibitions for women and, conversely, permissions for men. The literature we have surveyed details women's relationship with prohibitive mechanisms of gendered space and men's experience of subjectification by gender that we have incorporated into an existing term we borrow from Blumen and Tzafrir (2011, p. 71): "the spatialization of everyday life". "Space" here does not just act as a metaphor but refers to the segmenting of the material world into power's governance by abstract-but materially inclinedprocesses of gender.

First, Druze women face restricted access to the freedom of movement compared to that of men. In other words, mobility exists as a gendered phenomenon of material experience. At its most explicit, the operation of patriarchy in Druze society restricts women's access to specific spaces. Women leaving the village space unsupervised bear the negative social mark of qawya, or "strong independent woman." 6 These women face the brunt of the disciplinary mechanism of social gossip, leading even to accusations that they have violated standards of sexual honor (Barakat 2021, p. 10). Initially, women's pursuit of higher education was considered to violate honor by comingling with men unsupervised, without the presence of a mahram (Blumen and Tzafrir 2011, p. 76). Here, the insidious effects of gendered space both subject women to their male family members' will while forcing them into strict gender roles. For example, in her testimony regarding the evening commute from university to home by public transit, a woman, Belkis, expressed "moral panic" qualities that reflect the internalization of regimes of gossip and honor (Blumen and Tzafrir 2011, p. 76). This degree of patriarchal control even applies across age dynamics of mothers and sons/daughters (Barakat et al. 2018, p. 75). In one case, gossip was even deployed against a man deemed too caring for his daughter (Weiner-Levy 2011, p. 137). The disciplinary effects of gossip expand beyond an Israeli Druze context. Bennett (1999) similarly notes how gossip in Syria governs Druze women's marital lives. Since Druze society considers endogamous marriage essential for its survival, gossip emerges as a Foucauldian mechanism. As Bennett puts it, "Syria is not a large country, there are not many spaces to disappear. [The] Panopticon is not an inappropriate model for Syria. Both the state and one's community are watching. The tentacles of gossip and in-group surveillance reach far" (Bennett 1999, p. 164).

Multiple studies confirm a high degree of endogamous marriage in Israeli Druze society that manufactures this difficulty of "disappearance" (Vardi-Saliternik et al. 2002, p. 428; Klat and Khudr 1986, pp. 139-40). Connecting the question of surveillance to Belkis's narrative, we can witness the kinds of affective control exercised through panoptic means. She worries: "[w]hat if a [male] student or somebody else is already at the station? People [might] think we are together and talk [gossip]" (Blumen and Tzafrir 2011, p. 76). Even in cinematic representations of the Druze in Arabani and The Syrian Bride, men disgraced from their families for intermarriage-a transgression of more abstract space of Druze identity that governs marriage practices, symbolized by their depiction as mobile subjects through the motif of the car-must both confront their family's projection of shame onto them as well as that of the village onto the family (Adwan 2013; Riklis 2004). Gossip emerges in 
connection to improper mobility or spatial transgression, whether attending university for women or marrying outside the religion for men.

Both Belkis's anxiety and the men's shame of Arabani and The Syrian Bride reflect what Blumen and Tzafrir (2011, p. 71) term "the spatialization of everyday life" describes as to "[... ] how distances and movements turn into a matter of daily decision-making and daily practices." Although initially intended explicitly for their analysis of Druze women commuting to university, when broadly applied to Druze society, the "spatialization of everyday life" captures how subjectifying processes of gender that control everyday behavior (gossip) emerge in direct relation to space. Although daily life's spatialization may refer to the origins of power in a discursive sense, their effects signal its thoroughly material nature. In other words, the spatialization of everyday life refers to the moment the discursive becomes the material or overspills into such a realm, at the very least. By the very linguistic specificity of "spatialization," in its present tense as an active process, the term points to gendered space's constructed nature; gender does not naturally emerge from space but its manipulation by specific institutional bodies.

Like the Religious Council-with male members-capable of authoritatively interpreting Druze scripture, legislative bodies maintain an unequal distribution of privileges along gendered lines (Barakat 2021, pp. 5,7). A vital vector to this discussion lies in the question of Druze patriarchy's interaction with the state. Through both "segregation and co-optation," in Israel, the state cements a distinct Druze identity, which simultaneously allows them to maintain an unchanging, patriarchal organization of Druze society in the name of cultural autonomy. In this sense, otherwise "liberal" institutions remain complicit in upholding patriarchy via the distinction between specific cultural spaces. Saba-Sa'di and Sa'di (2017, p. 822) recognize the emergence of explicitly gendered institutional spaces in terms of the "uqqāl: "the strata of religious men [ . . . ] [who] have striven to impose [their] interpretation of social morality and ethics on the community as a whole, particularly on women."

Space also governs Druze men and women's navigation of educational spaces. Even with women allowed to attend their high schools fully-thus deviating from customary practices to send them to work or enter a marriage-women still face restrictions on their mobility within higher education (Barakat et al. 2018, p. 79; Beaini 1989, p. 42). In the Israeli case, many families prefer Druze women to attend teacher's colleges in hopes that they "work close to home" (Barakat et al. 2018, p. 80). Additionally, teacher's colleges reinforce Druze particularism by segregating Druze and Jewish women in separate education systems (Saba-Sa'di and Sa'di 2017, p. 823). For Druze boys, the institutional space of secondary education prepares them for conscription by fostering forms of military masculinity. While men benefit from the relative freedom of movement compared to the prohibitive mechanism of gendered space, it would be incorrect to say Druze men, especially in an Israeli context, move through the world as ungoverned subjects. "To govern" might refer both to processes of prohibition and processes of permission. In other words, gendered power and space operate negatively and positively-not in the sense of good and evil-but the sense of power's constructive and deconstructive faculties.

Furthermore, if we take the third-order concept of the spatialization of everyday life seriously, then what kinds of agential ideas does the existing literature offer? Agency represents a critical theoretical consequence of our systematic literature review. Many scholars studying gender in Druze society posit instances of Druze women's agency under the everyday weight of patriarchal duress. This meta-ethnographic analysis clarifies two critical factors of the agential question under Druze patriarchy: its individualist origin and its emphasis on mobility/flexibility.

Additionally, Barakat et al. (2018, p. 83) detail the practice of negotiation as critical to navigating the political dimension of the hamula's effect on employment. Weiner-Levy's (2011, p. 132) study of Druze fathers' support of their daughter's education details both women's practice of negotiation—invoked as "bargaining" or "interism" —as well as men's efforts to "upset the balance of power between the sexes." Negotiation also applies to an explicit struggle for mobility: women's right to drive. When the Druze textile factories, as 
aforementioned, were subsequently closed, it widened the geographic scope of women's labor participation and required more significant levels of education than low-skilled work. Considering women may drive with permission of their families, many testimonials attest to the fact of negotiation's increasing use to cement "Druze women driving cars in the 'Druze landscape' [as] gradually becoming a fact of life" (Barakat 2021, p. 17). Harris' (2013, pp. 96-98) analysis of Riklis' The Syrian Bride additionally notes the role of Druze women's negotiations in both the film and the context of Palestinian representation in Israeli cinema. As demonstrated by our literature review, agency for Druze women moves both below the radar and within the bounds of gendered space. Thus, one must think of the question of resistance as not abolishing areas like the public/private spheres of western feminist imagination. Instead, agency involves navigating the facts of gendered regulations to achieve "a public sphere [... ] allowing women more autonomy and control over their own lives" (Barakat et al. 2018, p. 65).

In proposition two, we suggested that the disparity in publications on Druze women and gender in Druze society between Israel and other countries like Lebanon, Syria, and Jordan relates to Druze particularism. Scholars refer to the term when explaining the government's role in engineering a distinct Druze identity within Israel (Saba-Sa'di and Sa'di 2017, p. 819). Again, the question here remains one of construction. The origins of Druze particularism begin with the invention of specific institutions, leadership positions, and councils after Israel's establishment. The process included, among other actions, the implementation of the Druze's mandatory conscription starting in 1956 as well as separating the Druze education system from that of the Arabs in 1977 (Zeedan 2019; Halabi 2018).

In one of the few articles centering Druze men as fathers, Florsheim and Gutmann (1992, p. 163) frame the Druze as "warriors [ . . . ] remain[ing] a proud and staunchly independent people". These authors' short aside in their article about Druze men's psychology provides a glimpse into the gendered image-making process that contributes to the consolidation of a specific Druze identity: that same kind of subjectification at the center of Saba-Sa'di and Sa'di's (2017, pp. 826-27) claims about Druze boys' militarization during schooling. Azzam (2007, p. xxii) laments this image-making process' tethering of Druze identity with patriarchy, calling for its necessity to "expose it as a cultural construct." Using the language of "image-making" allows the metaphor to access its critique of gender, militarization, and power and refers to a language of visibility that effectively conveys a disparity in publications on Druze women and gender in Druze society between Israel and other countries. In this context, meta-ethnography serves the purpose of elucidating "the full image" without its neat cropping by institutional and cultural authorities.

It is worth noting that the existing literature fails to provide a sufficient account of the contemporary status of Druze family law in Israel. Family law and marriage practices among the Druze are probably among the significant areas where the Druze experience distinctively differs from the other Palestinian Arabs in Israel. Not only that, the topic deserves further research. In addition, its absence itself calls for examination in light of our second proposition.

Our figures display the reality of the disparity in publications on Druze women and gender in Druze society and how it relates to Druze particularism. In Figure 1, we showed the difference between the collected articles' countries of focus over time. In the last two decades, the proportion of articles focusing on Israel against Lebanon and other countries hovers at around $71 \%$. Figure 2 demonstrated that Israeli university-affiliated scholars published about $69 \%$ of works collected in $2000-2009$ and 59\% in $2010-2019$. Israeli-affiliated scholars have published all works collected after 2020 about the Israeli Druze. The data demonstrate that Israel dominates existing research on Druze women and gender in Druze communities. The results of this systematic literature review point to multiple possibilities that warrant future investigation on the intersection between Druze particularism and its effect on academia, as well as its potentially gendered basis.

We thus conclude proposition two by attesting that the Druze identity in Israel possesses more visibility than Druze identity in Lebanon, Syria, Jordan, or other diasporic 
countries. In other words, the concept of Druzeness itself is at the core issue of the surplus of published research on Druze women and gender in Druze society. It is at the heart of this question: are the Druze a sect of Islam or a separate religion? In the Israeli context, the Druze are viewed as a different religion (Dana 2003). On the other hand, the discourse in other countries claims that the Druze are merely a sect of Islam (Azzam 2007). In this sense, the extensive body of research on the experiences of Druze women in Israel is made possible due to the conceptual and identitarian separation of the Druze from Muslims.

In other words, when the Druze in Syria, for example, consider themselves as part of the Islamic majority, then maybe they do not see it fit to conduct a significant body of research on their community separate from other Muslims. Likewise, the state apparatus and the Muslim Arab majority in Syria have no intention to separate the Druze, and hence, there is no incentive to research them separately from the majority. We suggest this to explain why the few publications on the Syrian Druze were done by outsiders to the Syrians and the Druze. Furthermore, there is a lack of census data on the Druze and other religions/ethnic groups in Lebanon, which complicates such research endeavors. These examples offer some contrast to the case in Israel. The Druze in Israel see themselves as different than the Jewish majority, but at the same time as separate from the Muslims. As such, some Druze scholars have intended to study their society separately from the others. The state apparatus and the Jewish majority are invested in separating the Druze from the other Arabs, specifically the Muslims. Finally, there is a systematic collection of data in Israel on the Druze, as other religious communities. Could the phenomenon of the influx in research on the Druze after 1999 be related to the Druze particularism? Could it be yet another step in the process of Druze particularism in Israel? These questions deserve further examination.

\section{Future Trajectories}

This systematic literature review has revealed future trajectories for research at the intersection of Druze Studies and feminist anthropology and sociology. In general, there is a lack of monographs or edited books explicitly focusing on the topic. In some areas, more than others, there is an over-representation of research on Druze women and gender in Druze society in Israel and a lack of such research on the Druze in Syria, Lebanon, Jordan, or the diaspora. This is especially true for research on education, economy, and health. Hence, this might create a misleading account of the status of Druze women and gender in Druze society within these topics if it heavily focuses on the experiences of one country, which includes a minority of the Druze. Targeting this lacuna is of high importance to reflect an unbiased account of these topics.

This literature review does not feature extensive research on Syria, Jordan, and the Druze diasporic communities or comparisons between countries. This points to a possible future path for gender perspectives within Druze Studies, while comparing and contrasting their situation within and between nations. Such future research could also use more quantitative research methods to complement the existing scholarship dominated by qualitative methods.

Other gaps were shown in this survey. Another missing component in the literature is examining the role of Druze women in direct religious settings, such as in prayers and official religious ceremonies. We also point to the lack of contemporary research regarding Druze family law, even in Israel. Such missing research will examine the legal regime that governs family life and the related practices. Our survey showed that existing scholarship on marriage and family is the most outdated. Rapid changes in society have not been caught up by contemporary research, thus significantly undervaluing the relevance of previous publications in understanding current trends. A critical gap exists in research on Druze men from an explicitly feminist perspective. Additionally, gaps include the lack of meaningful publications on influential Druze women. There is a need to fill these gaps in future research projects. 
Furthermore, in this type of research, we could not include more demographic information about the authors. It would be fruitful to examine the gender divide of authors writing about this topic and whether Druze authors, while accounting for gender disparities, contribute to the subject more than others, as it might seem in the past two decades. With the increase of access to education among the Druze, particularly women in Israel, could this explain the increase in research and publications on the Druze since the late 1990s? Could the explanation of more research conducted on the status of Lebanese-Druze women by scholars outside of Lebanon be related to the considerably larger LebaneseDruze diaspora communities? These are yet other examples for future research derived from this review.

Finally, additional work could be done to survey publications on the topic in other languages. This is specifically true in Arabic and Hebrew regarding the Druze in the Middle East. Such an expanded approach could also benefit from including potential publications in other languages, e.g., in French, Spanish, or Portuguese concerning the Lebanese-Druze or some of the Druze diaspora communities.

Author Contributions: Both authors contributed equally. All authors have read and agreed to the published version of the manuscript.

Funding: This research received no external funding.

Institutional Review Board Statement: Not applicable.

Informed Consent Statement: Not applicable.

Acknowledgments: We wish to thank the Danciger Fund of the Jewish Community Foundation of Greater Kansas City for providing research scholarship support in Jewish Studies, and the University of Kansas Jewish Studies program, for their support of the research project that led to this publication.

Conflicts of Interest: The authors declare no conflict of interest. 


\section{Appendix A}

Table A1. List of publications.

\begin{tabular}{|c|c|c|c|c|c|c|c|c|}
\hline $\begin{array}{l}\text { Running } \\
\text { Number }\end{array}$ & Author & $\begin{array}{l}\text { Primary Author } \\
\text { Affiliation by } \\
\text { Country }\end{array}$ & $\begin{array}{l}\text { Country of } \\
\text { Focus }\end{array}$ & $\begin{array}{c}\text { Type of } \\
\text { Publication }\end{array}$ & Discipline & Method & $\begin{array}{c}\text { Focuses on the } \\
\text { Druze/Compared } \\
\text { to Others }\end{array}$ & $\begin{array}{l}\text { Contributing to } \\
\text { Theory/Major Findings }\end{array}$ \\
\hline 1 & $\begin{array}{l}\text { Abbas et al. } \\
\qquad(2018)\end{array}$ & Israel & Israel & $\begin{array}{l}\text { Article (Journal of } \\
\text { Adolescent } \\
\text { Research) }\end{array}$ & Sociology & $\begin{array}{l}\text { Thematic content analysis } \\
\text { on selected interviews: } 12 \\
\text { Druze adolescents, six boys, } \\
\text { and six girls, age 16-18 }\end{array}$ & $\begin{array}{l}\text { Focuses on the } \\
\text { Druze }\end{array}$ & $\begin{array}{c}\text { Adolescent application of } \\
\text { Weiner-Levy's concept of } \\
\text { "hybridity". }\end{array}$ \\
\hline 2 & Adwan (2013) & Israel & Israel & Film & Film & Drama movie & $\begin{array}{l}\text { Focuses on the } \\
\text { Druze }\end{array}$ & $\begin{array}{c}\text { Intermarried man } \\
\text { application of } \\
\text { Weiner-Levy's concept of } \\
\text { "hybridity". }\end{array}$ \\
\hline 3 & $\begin{array}{l}\text { Alamuddin and } \\
\text { Starr (1980), } \\
\text { chp. } 4\end{array}$ & Lebanon, & Lebanon & Book Chapter & Sociology & $\begin{array}{l}\text { Analysis of variance on } \\
\text { mahr in Lebanese Druze } \\
\text { marriage contracts }\end{array}$ & $\begin{array}{l}\text { Focuses on the } \\
\text { Druze }\end{array}$ & $\begin{array}{c}\text { Connects marriage to social } \\
\text { values }\end{array}$ \\
\hline 4 & $\begin{array}{l}\text { Amer-Alshiek } \\
\text { et al. (2015) }\end{array}$ & United States & Israel & $\begin{array}{c}\text { Article (Israel } \\
\text { Journal of Health } \\
\text { Policy Research) }\end{array}$ & $\begin{array}{l}\text { Health and } \\
\text { Medicine }\end{array}$ & $\begin{array}{l}\text { Statistical analysis on } 196 \\
\text { questionnaires distributed } \\
\text { by } 5 \text { Israeli gynecologists }\end{array}$ & $\begin{array}{l}\text { Focuses on the } \\
\text { Druze }\end{array}$ & $\begin{array}{l}\text { Connects religiosity to the } \\
\text { preference of } \\
\text { obstetricians/gynecologists }\end{array}$ \\
\hline 6 & $\begin{array}{l}\text { Barakat et al. } \\
\qquad(2018)\end{array}$ & Israel & Israel & $\begin{array}{l}\text { Article (Journal of } \\
\text { Research in } \\
\text { Gender Studies) }\end{array}$ & Gender Studies & $\begin{array}{c}\text { Feminist narrative } \\
\text { approach and } \\
\text { semi-structured interviews } \\
\text { of } 60 \text { Druze women aged } 30 \\
\text { to } 50\end{array}$ & $\begin{array}{l}\text { Focuses on the } \\
\text { Druze }\end{array}$ & $\begin{array}{l}\text { Reveals limits of Western } \\
\text { Feminist "public/private" } \\
\text { binary }\end{array}$ \\
\hline 7 & Barakat (2021) & Israel & Israel & $\begin{array}{l}\text { Article (Gender } \\
\text { Issues) }\end{array}$ & Gender Studies & $\begin{array}{c}\text { Intersectional analysis and } \\
\text { semi-structured interviews, } \\
60 \text { Druze women aged } 30 \\
\text { to } 50\end{array}$ & $\begin{array}{l}\text { Focuses on the } \\
\text { Druze }\end{array}$ & $\begin{array}{c}\text { Names concealment } \\
\text { (istighāba) as resistance to } \\
\text { spatial gender prohibitions }\end{array}$ \\
\hline
\end{tabular}


Table A1. Cont.

\begin{tabular}{|c|c|c|c|c|c|c|c|c|}
\hline $\begin{array}{l}\text { Running } \\
\text { Number }\end{array}$ & Author & $\begin{array}{l}\text { Primary Author } \\
\text { Affiliation by } \\
\text { Country }\end{array}$ & $\begin{array}{l}\text { Country of } \\
\text { Focus }\end{array}$ & $\begin{array}{c}\text { Type of } \\
\text { Publication }\end{array}$ & Discipline & Method & $\begin{array}{c}\text { Focuses on the } \\
\text { Druze/Compared } \\
\text { to Others }\end{array}$ & $\begin{array}{l}\text { Contributing to } \\
\text { Theory/Major Findings }\end{array}$ \\
\hline 8 & $\begin{array}{l}\text { Beaini (1989), } \\
\text { chp. } 4\end{array}$ & United States & Lebanon & $\begin{array}{l}\text { Unpublished MA } \\
\text { Thesis }\end{array}$ & Anthropology & $\begin{array}{l}\text { Participant-observation and } \\
\text { questionnaires }\end{array}$ & $\begin{array}{l}\text { Focuses on the } \\
\text { Druze }\end{array}$ & $\begin{array}{c}\text { Comprehensive } \\
\text { anthropological account of } \\
\text { Lebanese Druze marriage } \\
\text { practices }\end{array}$ \\
\hline 9 & $\begin{array}{l}\text { Blumen and } \\
\text { Halevi (2005) }\end{array}$ & Israel & Israel & Article (Identities) & Gender Studies & $\begin{array}{c}\text { Interviews: } 12 \text { Jewish } \\
\text { women and } 11 \text { Palestinian } \\
\text { women }\end{array}$ & $\begin{array}{l}\text { Compared to } \\
\text { Others }\end{array}$ & $\begin{array}{c}\text { Druze perspective from } \\
\text { within the Women's Studies } \\
\text { classroom }\end{array}$ \\
\hline 10 & $\begin{array}{l}\text { Blumen and } \\
\text { Tzafrir (2011) }\end{array}$ & Israel & Israel & $\begin{array}{l}\text { Article (Cultural } \\
\text { Analysis) }\end{array}$ & Gender Studies & $\begin{array}{c}\text { Semi-structured interviews: } \\
22 \text { young Druze female } \\
\text { students }\end{array}$ & $\begin{array}{l}\text { Focuses on the } \\
\text { Druze }\end{array}$ & $\begin{array}{l}\text { Theorizes gender } \\
\text { prohibitions in spatial and } \\
\text { temporal frames, one of the } \\
\text { critical articles of this } \\
\text { literature review's } \\
\text { hypothesis }\end{array}$ \\
\hline 11 & $\begin{array}{l}\text { Charafeddine } \\
\text { (2010) }\end{array}$ & Lebanon & Lebanon & Article (al-raida) & Sociology & $\begin{array}{c}\text { Survey of marriage } \\
\text { contracts and } \\
\text { selected-sample interviews: } \\
\text { 13 Sunnis, } 9 \text { Shiites, } 4 \text { Druze, } \\
\text { 8 Christians }\end{array}$ & $\begin{array}{l}\text { Compared to } \\
\text { Others }\end{array}$ & $\begin{array}{l}\text { Provides data on Druze } \\
\text { marriage contracts in } \\
\text { Lebanon }\end{array}$ \\
\hline 12 & Daoud (2006) & United States & Israel & $\begin{array}{l}\text { Article (Middle } \\
\text { East Report) }\end{array}$ & Political Science & Interviews of Arab MKs & $\begin{array}{l}\text { Compared to } \\
\text { Others }\end{array}$ & $\begin{array}{l}\text { Mentions Druze women in } \\
\text { politics }\end{array}$ \\
\hline 13 & Dayan (2019) & Israel & Israel & $\begin{array}{l}\text { Article (Journal of } \\
\text { Interpersonal } \\
\text { Violence) }\end{array}$ & Sociology & $\begin{array}{l}\text { Statistical Analysis of data } \\
\text { from the Israeli CBS and } \\
\text { media surveillance of } \\
58 \text { honor killings cases }\end{array}$ & $\begin{array}{l}\text { Compared to } \\
\text { Others }\end{array}$ & $\begin{array}{c}\text { Tracks sociological factors } \\
\text { in instances of honor } \\
\text { killings }\end{array}$ \\
\hline 14 & Di Ricco (2012) & Colombia & Lebanon & Book Chapter & Gender Studies & $\begin{array}{c}\text { Interviews with a Druze } \\
\text { female activist in Lebanon } \\
\text { and a Druze judge }\end{array}$ & $\begin{array}{l}\text { Focuses on the } \\
\text { Druze }\end{array}$ & $\begin{array}{c}\text { Overview on Druze } \\
\text { women's activism in } \\
\text { Lebanese Personal Status } \\
\text { Law }\end{array}$ \\
\hline
\end{tabular}


Table A1. Cont.

\begin{tabular}{|c|c|c|c|c|c|c|c|c|}
\hline $\begin{array}{l}\text { Running } \\
\text { Number }\end{array}$ & Author & $\begin{array}{l}\text { Primary Author } \\
\text { Affiliation by } \\
\text { Country }\end{array}$ & $\begin{array}{c}\text { Country of } \\
\text { Focus }\end{array}$ & $\begin{array}{c}\text { Type of } \\
\text { Publication }\end{array}$ & Discipline & Method & $\begin{array}{c}\text { Focuses on the } \\
\text { Druze/Compared } \\
\text { to Others }\end{array}$ & $\begin{array}{l}\text { Contributing to } \\
\text { Theory/Major Findings }\end{array}$ \\
\hline 15 & $\begin{array}{l}\text { Florsheim and } \\
\text { Gutmann (1992) }\end{array}$ & United States & Israel & $\begin{array}{c}\text { Article } \\
\text { (Psychiatry) }\end{array}$ & Psychology & $\begin{array}{l}\text { Unstructured interviews: } \\
\text { Druze men aged 35-90 }\end{array}$ & $\begin{array}{l}\text { Focuses on the } \\
\text { Druze }\end{array}$ & $\begin{array}{l}\text { One of the sole inquiries } \\
\text { into Druze men's gendered } \\
\text { position within the family }\end{array}$ \\
\hline 16 & $\begin{array}{l}\text { Fournier et al. } \\
\qquad(2018)\end{array}$ & Canada & Lebanon & Book Chapter & $\begin{array}{c}\text { Gender } \\
\text { Studies/Law }\end{array}$ & $\begin{array}{l}\text { Interviews: Sunni and } \\
\text { Shiite Muslims, Druze, } \\
\text { Melkite and Maronite } \\
\text { Christians, Greek Orthodox, } \\
\text { Armenian Orthodox }\end{array}$ & $\begin{array}{l}\text { Compared to } \\
\text { Others }\end{array}$ & $\begin{array}{c}\text { Provides feminist } \\
\text { perspective for Lebanese } \\
\text { debate over religious and } \\
\text { secular marriage, elaborates } \\
\text { on complexity } \\
\text { public/private binary }\end{array}$ \\
\hline 17 & Geiger (2013) & Israel & Israel & $\begin{array}{c}\text { Article } \\
\text { (International } \\
\text { Journal of Higher } \\
\text { Education) }\end{array}$ & Education & $\begin{array}{l}\text { Interviews: } 42 \text { Arab women } \\
\text { students, } 12 \text { Druze, } \\
22 \text { Muslims, } 8 \text { Christians }\end{array}$ & $\begin{array}{l}\text { Compared to } \\
\text { Others }\end{array}$ & $\begin{array}{l}\text { Details Druze women's } \\
\text { experience of acculturation } \\
\text { within the University, } \\
\text { Druze women detailed } \\
\text { feelings of alienation }\end{array}$ \\
\hline 18 & Golan (2015) & Israel & Israel & $\begin{array}{l}\text { Article (Journal of } \\
\text { Psychology and } \\
\text { Clinical } \\
\text { Psychiatry) }\end{array}$ & Psychology & Literature Review & $\begin{array}{l}\text { Focuses on the } \\
\text { Druze }\end{array}$ & $\begin{array}{l}\text { Centers on questions of } \\
\text { Druze women's beauty and } \\
\text { health, both undercovered } \\
\text { in the field }\end{array}$ \\
\hline 19 & $\begin{array}{l}\text { Goldblatt and } \\
\text { Granot (2006) }\end{array}$ & Israel & Israel & $\begin{array}{c}\text { Article (Women \& } \\
\text { Health) }\end{array}$ & $\begin{array}{c}\text { Health and } \\
\text { Medicine/Gender } \\
\text { Studies }\end{array}$ & $\begin{array}{c}\text { Questionnaires: } \\
100 \text { participants at primary } \\
\text { care clinics }\end{array}$ & $\begin{array}{l}\text { Focuses on the } \\
\text { Druze }\end{array}$ & $\begin{array}{l}\text { Outlines strategies for } \\
\text { confronting physical abuse } \\
\text { within the patriarchal } \\
\text { culture that disincentivizes } \\
\text { reporting those instances of } \\
\text { abuse }\end{array}$ \\
\hline 20 & Halabi (2013) & Lebanon & Lebanon & Book chapter & Law & $\begin{array}{l}\text { Personal experience of the } \\
\text { author as a former judge } \\
\text { and text analysis }\end{array}$ & $\begin{array}{l}\text { Focuses on the } \\
\text { Druze }\end{array}$ & $\begin{array}{l}\text { Details the legal status of } \\
\text { Druze in Lebanon }\end{array}$ \\
\hline
\end{tabular}


Table A1. Cont.

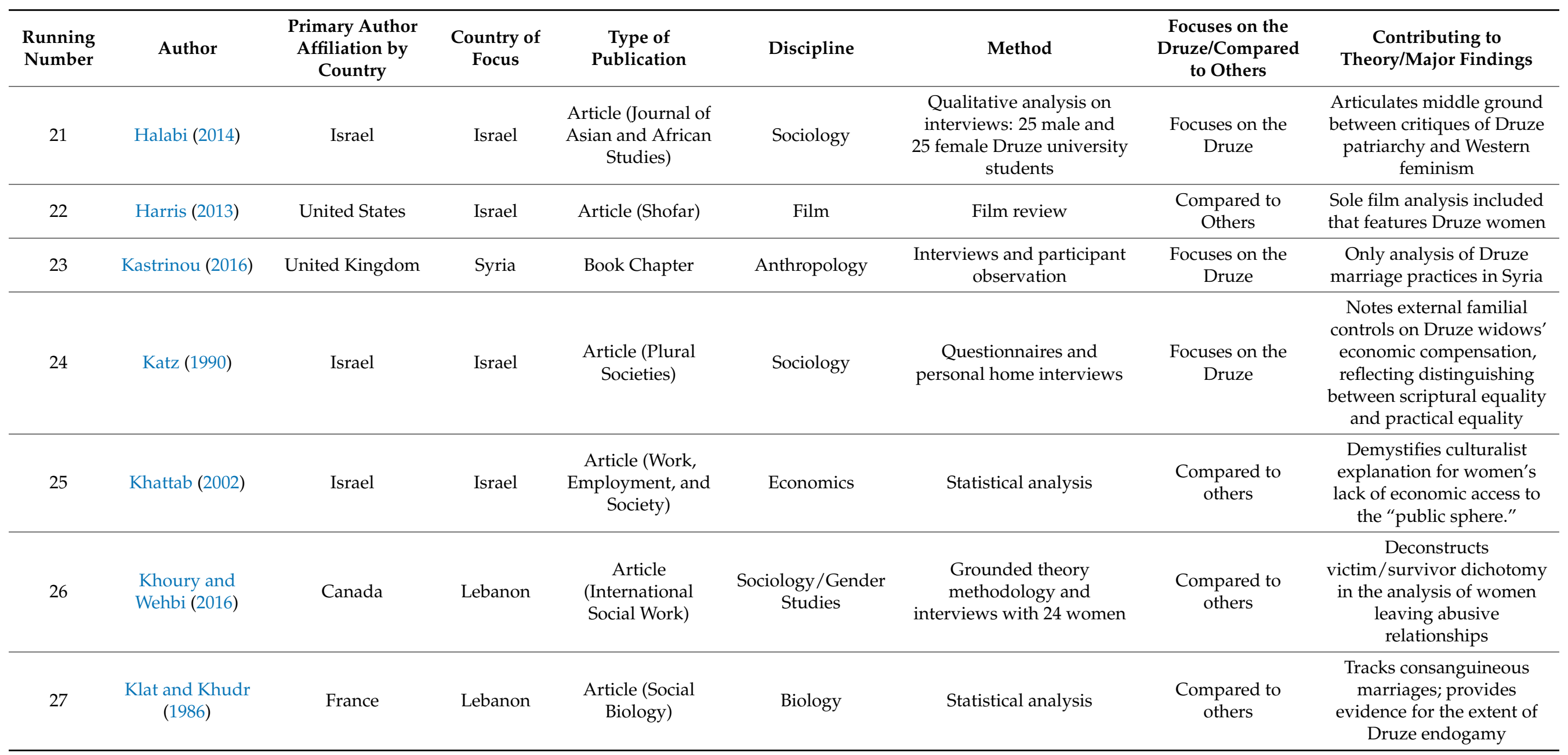


Table A1. Cont.

\begin{tabular}{|c|c|c|c|c|c|c|c|c|}
\hline $\begin{array}{l}\text { Running } \\
\text { Number }\end{array}$ & Author & $\begin{array}{l}\text { Primary Author } \\
\text { Affiliation by } \\
\text { Country }\end{array}$ & $\begin{array}{l}\text { Country of } \\
\text { Focus }\end{array}$ & $\begin{array}{c}\text { Type of } \\
\text { Publication }\end{array}$ & Discipline & Method & $\begin{array}{c}\text { Focuses on the } \\
\text { Druze/Compared } \\
\text { to Others }\end{array}$ & $\begin{array}{l}\text { Contributing to } \\
\text { Theory/Major Findings }\end{array}$ \\
\hline 28 & $\begin{array}{l}\text { Kraus and Yonay } \\
\qquad \text { (2013) }\end{array}$ & Israel & Israel & $\begin{array}{l}\text { Article } \\
\text { (Palestinians in the } \\
\text { Israeli Labor } \\
\text { Market) }\end{array}$ & Economics & $\begin{array}{l}\text { Statistical analysis of data } \\
\text { from the Israeli CBS }\end{array}$ & $\begin{array}{l}\text { Compared to } \\
\text { others }\end{array}$ & $\begin{array}{l}\text { Provides statistical } \\
\text { economic profile for Druze } \\
\text { women over time in } \\
\text { comparison to other } \\
\text { ethnicities and religions }\end{array}$ \\
\hline 29 & $\begin{array}{l}\text { Yonay et al. } \\
\qquad(2014)\end{array}$ & Israel & Israel & Article (Sociology) & Economics & $\begin{array}{l}\text { Statistical analysis of data } \\
\text { from the Israeli CBS }\end{array}$ & $\begin{array}{l}\text { Compared to } \\
\text { others }\end{array}$ & $\begin{array}{l}\text { Follows Khattab (2002) in } \\
\text { disproving culturalist } \\
\text { accounts of Druze women's } \\
\text { economic participation, } \\
\text { locates lurking variable in } \\
\text { higher heterogeneous levels } \\
\text { of financial involvement by } \\
\text { Christian economic } \\
\text { privilege in Israel }\end{array}$ \\
\hline 30 & $\begin{array}{l}\text { Kraus and Yonay } \\
\qquad(2016)\end{array}$ & Israel & Israel & Book Chapter & Economics & $\begin{array}{l}\text { Statistical analysis of data } \\
\text { from the Israeli CBS }\end{array}$ & $\begin{array}{l}\text { Compared to } \\
\text { others }\end{array}$ & $\begin{array}{c}\text { Finds more significant } \\
\text { public sector advantages for } \\
\text { Jewish and Druze women } \\
\text { over Muslim and Christian } \\
\text { Women, reflecting Druze } \\
\text { particularism }\end{array}$ \\
\hline 31 & $\begin{array}{l}\text { Kraus and Yonay } \\
\qquad(2018)\end{array}$ & Israel & Israel & Book Chapter & Economics & $\begin{array}{l}\text { Statistical analysis of data } \\
\text { from the Israeli CBS }\end{array}$ & $\begin{array}{l}\text { Focuses on the } \\
\text { Druze }\end{array}$ & $\begin{array}{l}\text { A most recent account of } \\
\text { Druze women's economic } \\
\text { profile with comparative } \\
\text { analysis }\end{array}$ \\
\hline 32 & Layish (1978) & Israel & Israel & $\begin{array}{l}\text { Article (Bulletin of } \\
\text { the School of } \\
\text { Oriental and } \\
\text { African Studies) }\end{array}$ & Law & Text analysis & $\begin{array}{l}\text { Focuses on the } \\
\text { Druze }\end{array}$ & $\begin{array}{l}\text { Details legal specificity of } \\
\text { divorce as well as } \\
\text { contemporary opinions on } \\
\text { the matter }\end{array}$ \\
\hline
\end{tabular}


Table A1. Cont.

\begin{tabular}{|c|c|c|c|c|c|c|c|c|}
\hline $\begin{array}{l}\text { Running } \\
\text { Number }\end{array}$ & Author & $\begin{array}{l}\text { Primary Author } \\
\text { Affiliation by } \\
\text { Country }\end{array}$ & $\begin{array}{l}\text { Country of } \\
\text { Focus }\end{array}$ & $\begin{array}{c}\text { Type of } \\
\text { Publication }\end{array}$ & Discipline & Method & $\begin{array}{l}\text { Focuses on the } \\
\text { Druze/Compared } \\
\text { to Others }\end{array}$ & $\begin{array}{l}\text { Contributing to } \\
\text { Theory/Major Findings }\end{array}$ \\
\hline 33 & Layish (1979) & Israel & Israel & $\begin{array}{l}\text { Article (Journal of } \\
\text { the American } \\
\text { Oriental Society) }\end{array}$ & Law & Text analysis & $\begin{array}{l}\text { Focuses on the } \\
\text { Druze }\end{array}$ & $\begin{array}{c}\text { Historicizes Druze ban on } \\
\text { polygamy }\end{array}$ \\
\hline 34 & Layish (1982) & Israel & $\begin{array}{l}\text { Lebanon } \\
\text { and Jordan }\end{array}$ & Book Chapter & Law & $\begin{array}{c}\text { Analysis of marriage } \\
\text { contract and statistical } \\
\text { analysis }\end{array}$ & $\begin{array}{l}\text { Focuses on the } \\
\text { Druze }\end{array}$ & $\begin{array}{l}\text { Acknowledges declining } \\
\text { presence of equality in } \\
\text { marriage laws as well as } \\
\text { increasing rates of Druze } \\
\text { exogamous marriages }\end{array}$ \\
\hline 35 & Mra'ana (2008) & Israel & Israel & Film & Film & Documentary movie & $\begin{array}{c}\text { Focuses on the } \\
\text { Druze }\end{array}$ & $\begin{array}{c}\text { Demonstrates the } \\
\text { prohibitive concept of } \\
\text { "honor" in the context of } \\
\text { Duah's attempt to } \\
\text { participate in an Israeli } \\
\text { Pageant }\end{array}$ \\
\hline 36 & Obeid (2006) & Lebanon & Mixed & Book chapter & History & Primary sources & $\begin{array}{l}\text { Focuses on the } \\
\text { Druze }\end{array}$ & $\begin{array}{l}\text { Explains the equal rights in } \\
\text { marriage, divorce, and } \\
\text { inheritance of Druze } \\
\text { women that contradict } \\
\text { Islamic traditions }\end{array}$ \\
\hline 37 & $\begin{array}{l}\text { Offer and Sabah } \\
\text { (2011) }\end{array}$ & Israel & Israel & $\begin{array}{l}\text { Article (Marriage } \\
\& \text { Family Review) }\end{array}$ & Economics & Statistical analysis & $\begin{array}{l}\text { Compared to } \\
\text { Others }\end{array}$ & $\begin{array}{l}\text { Like others, attributes } \\
\text { textile factory placement as } \\
\text { instrumental in Druze } \\
\text { women's greater economic } \\
\text { participation }\end{array}$ \\
\hline 38 & $\begin{array}{l}\text { Oppenheimer } \\
\text { (1980) }\end{array}$ & Israel & Israel & $\begin{array}{l}\text { Article (American } \\
\text { Ethnologist) }\end{array}$ & Anthropology & Literature Review & $\begin{array}{l}\text { Focuses on the } \\
\text { Druze }\end{array}$ & $\begin{array}{c}\text { A comprehensive } \\
\text { anthropological account } \\
\text { contextualizes gender roles } \\
\text { to reincarnation }\end{array}$ \\
\hline
\end{tabular}


Table A1. Cont.

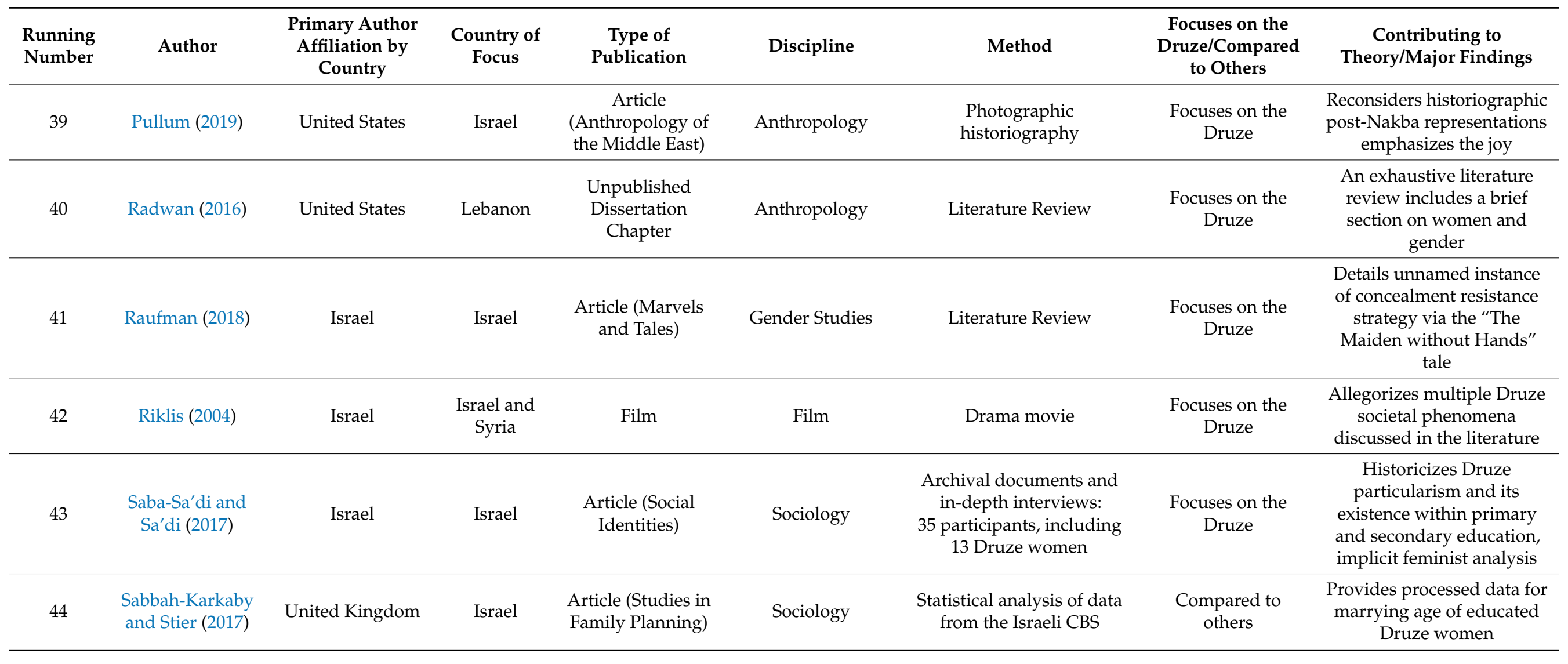


Table A1. Cont.

\begin{tabular}{|c|c|c|c|c|c|c|c|c|}
\hline $\begin{array}{l}\text { Running } \\
\text { Number }\end{array}$ & Author & $\begin{array}{l}\text { Primary Author } \\
\text { Affiliation by } \\
\text { Country }\end{array}$ & $\begin{array}{l}\text { Country of } \\
\text { Focus }\end{array}$ & $\begin{array}{c}\text { Type of } \\
\text { Publication }\end{array}$ & Discipline & Method & $\begin{array}{c}\text { Focuses on the } \\
\text { Druze/Compared } \\
\text { to Others }\end{array}$ & $\begin{array}{l}\text { Contributing to } \\
\text { Theory/Major Findings }\end{array}$ \\
\hline 45 & $\begin{array}{l}\text { Sasson-Levy } \\
\quad(2017)\end{array}$ & Israel & Israel & Book Chapter & Sociology & Intersectional analysis & $\begin{array}{l}\text { Compared to } \\
\text { others }\end{array}$ & $\begin{array}{l}\text { Analyzes Druze men's } \\
\text { military conscription and } \\
\text { Druze women's ban from } \\
\text { enlistment from a feminist } \\
\text { perspective }\end{array}$ \\
\hline 46 & $\begin{array}{l}\text { Shamma and } \\
\text { Asaqli (2020) }\end{array}$ & Israel & Israel & $\begin{array}{l}\text { Article (Journal of } \\
\text { Educational and } \\
\text { Developmental } \\
\text { Psychology) }\end{array}$ & Sociology & $\begin{array}{c}\text { An in-depth structured } \\
\text { questionnaire: } \\
243 \text { participants aged 15-18, } \\
124 \text { Druze, } 119 \text { Jewish }\end{array}$ & $\begin{array}{l}\text { Compared to } \\
\text { others }\end{array}$ & $\begin{array}{l}\text { Showcases changes in } \\
\text { gender-based attitudes } \\
\text { about Druze adolescent } \\
\text { girls' autonomy in } \\
\text { decision-making, compared } \\
\text { to Jewish girls }\end{array}$ \\
\hline 47 & Stier (2013) & Israel & Israel & Book Chapter & Economics & $\begin{array}{l}\text { Statistical analysis of data } \\
\text { from the Israeli CBS }\end{array}$ & $\begin{array}{l}\text { Compared to } \\
\text { others }\end{array}$ & $\begin{array}{l}\text { Correlates greater } \\
\text { education and declining } \\
\text { fertility rate with Druze } \\
\text { women's economic } \\
\text { participation }\end{array}$ \\
\hline 48 & Swayd (2009) & United States & Mixed & $\begin{array}{l}\text { Book } \\
\text { (Encyclopedia } \\
\text { guide) }\end{array}$ & History & $\begin{array}{l}\text { Literature review and } \\
\text { primary sources }\end{array}$ & $\begin{array}{l}\text { Focuses on the } \\
\text { Druze }\end{array}$ & $\begin{array}{l}\text { Names a few influential } \\
\text { Druze women in history }\end{array}$ \\
\hline 49 & Tarabey (2013) & Lebanon & Lebanon & Book Chapter & Sociology & $\begin{array}{l}\text { Comparative study of } \\
\text { marriage and divorce rates } \\
(1970-2003)\end{array}$ & $\begin{array}{l}\text { Focuses on the } \\
\text { Druze }\end{array}$ & $\begin{array}{c}\text { Tests a variety of factors in } \\
\text { instances of Druze marriage } \\
\text { and divorce }\end{array}$ \\
\hline 50 & $\begin{array}{l}\text { Vardi-Saliternik } \\
\text { et al. (2002) }\end{array}$ & Israel & Israel & $\begin{array}{l}\text { Article (Annals of } \\
\text { Human Biology) }\end{array}$ & Biology & $\begin{array}{l}\text { Structured questionnaire in } \\
\text { 1990-1992: } 6001 \text { women } \\
\text { interviewed, } 1529 \text { were } \\
\text { "Arab and Druze" }\end{array}$ & $\begin{array}{l}\text { Compared to } \\
\text { others }\end{array}$ & $\begin{array}{l}\text { Provides additional data } \\
\text { that reflects the degree of } \\
\text { Druze endogamy }\end{array}$ \\
\hline
\end{tabular}


Table A1. Cont.

\begin{tabular}{|c|c|c|c|c|c|c|c|c|}
\hline $\begin{array}{l}\text { Running } \\
\text { Number }\end{array}$ & Author & $\begin{array}{l}\text { Primary Author } \\
\text { Affiliation by } \\
\text { Country }\end{array}$ & $\begin{array}{l}\text { Country of } \\
\text { Focus }\end{array}$ & $\begin{array}{c}\text { Type of } \\
\text { Publication }\end{array}$ & Discipline & Method & $\begin{array}{c}\text { Focuses on the } \\
\text { Druze/Compared } \\
\text { to Others }\end{array}$ & $\begin{array}{l}\text { Contributing to } \\
\text { Theory/Major Findings }\end{array}$ \\
\hline 51 & $\begin{array}{l}\text { Weiner-Levy } \\
\text { (2008a) }\end{array}$ & Israel & Israel & $\begin{array}{l}\text { Article } \\
\text { (Qualitative } \\
\text { Inquiry) }\end{array}$ & Education & $\begin{array}{c}\text { Open-ended questions and } \\
\text { interviews: } 34 \text { Druze } \\
\text { women }\end{array}$ & $\begin{array}{c}\text { Focuses on the } \\
\text { Druze }\end{array}$ & $\begin{array}{l}\text { Provides insight on the } \\
\text { positionality of the } \\
\text { researcher and researched } \\
\text { in the context of interviews } \\
\text { with Druze women }\end{array}$ \\
\hline 52 & $\begin{array}{l}\text { Weiner-Levy } \\
\text { (2008b) }\end{array}$ & Israel & Israel & $\begin{array}{l}\text { Article (Gender } \\
\text { and Education) }\end{array}$ & $\begin{array}{c}\text { Education/Gender } \\
\text { Studies }\end{array}$ & $\begin{array}{l}\text { Interviews in 1998-2002: } \\
34 \text { Druze women }\end{array}$ & $\begin{array}{l}\text { Focuses on the } \\
\text { Druze }\end{array}$ & $\begin{array}{l}\text { Provides concept of } \\
\text { "hybridity" for Druze } \\
\text { women attending higher } \\
\text { education }\end{array}$ \\
\hline 53 & $\begin{array}{l}\text { Weiner-Levy } \\
\text { (2009) }\end{array}$ & Israel & Israel & $\begin{array}{c}\text { Article } \\
\text { (International } \\
\text { Journal for } \\
\text { Educational } \\
\text { Development) }\end{array}$ & $\begin{array}{l}\text { Education/Gender } \\
\text { Studies }\end{array}$ & $\begin{array}{l}\text { Interviews in 1998-2002: } \\
34 \text { Druze women }\end{array}$ & $\begin{array}{l}\text { Focuses on the } \\
\text { Druze }\end{array}$ & $\begin{array}{l}\text { Details processes of } \\
\text { alienation along with the } \\
\text { experience of "hybridity" } \\
\text { that Druze women } \\
\text { experience when attending } \\
\text { higher education }\end{array}$ \\
\hline 55 & $\begin{array}{l}\text { Yehya and Dutta } \\
\text { (2010) }\end{array}$ & United States & Lebanon & $\begin{array}{c}\text { Article } \\
\text { (Qualitative } \\
\text { Health Research) }\end{array}$ & $\begin{array}{c}\text { Health and } \\
\text { Medicine/Gender } \\
\text { Studies }\end{array}$ & $\begin{array}{l}\text { Interviews in 2008: } \\
13 \text { women and ten } \\
\text { daughters }\end{array}$ & $\begin{array}{l}\text { Focuses on the } \\
\text { Druze }\end{array}$ & $\begin{array}{l}\text { Situates notions of "health" } \\
\text { in the context of Druze } \\
\text { women's experience }\end{array}$ \\
\hline 56 & $\begin{array}{c}\text { Zaatut and } \\
\text { Haj-Yahia (2016) }\end{array}$ & Israel & Israel & $\begin{array}{l}\text { Article (Feminism } \\
\text { and Psychology) }\end{array}$ & $\begin{array}{l}\text { Sociology/Gender } \\
\text { Studies }\end{array}$ & $\begin{array}{c}\text { Self-administered } \\
\text { questionnaire: } 701 \text { married } \\
\text { Palestinian women }\end{array}$ & $\begin{array}{l}\text { Compared to } \\
\text { others }\end{array}$ & $\begin{array}{l}\text { Comparative analysis of } \\
\text { patriarchal attitudes among } \\
\text { Druze women regarding } \\
\text { wife-beating in contrast to } \\
\text { other ethnic and religious } \\
\text { groups in Israel further } \\
\text { demystifies "women vs. } \\
\text { men" culturalist explanation } \\
\text { of Arab patriarchy }\end{array}$ \\
\hline
\end{tabular}




\section{Notes}

1 The Druze society is generaly comprised of two internally distinct groups: $u q q \bar{q}$ l are those initiated into the sacred knowledge of the faith, and juhhāl are those uninitiated (Betts 1988). Sometimes they are also referred to as ruhani vs. jismani. Ruhani is for the mashaeikh (Sheikh for singular) who are the $u q q \bar{a} l$, those concerned with the physical world as opposed to jismani, who are the juhhāl and are concerned with the body (Ben-Dor 1976).

2 A detailed contemporary account of Druze legal rights in marriage and divorce is provided by Layish (1978, 1979, 1982).

3 Taqiyya ("dissimulation" from Arabic) is the practice of: "[ . . ] ] adoption of outward forms of Sunni Islamic rituals in order to protect the inward faith. The Druze practice of taqiyya is nearly the same sense of the Isma'ili and 'Alawi principle." (Firro 2001).

4 Hamula is a kinship-based structure in which the extended family playes a central role in many aspects of society, such as the economy, politics, and marraige. Is is organized by lineage of families or a few extended families (Rosenfeld 1974).

5 In this context, a mahram is a male relative acting as chaperone who must escort a Druze woman leaving the village. Otherwise she- or her family - might face excommunication or rumors that she violates standards of sexual honor (Barakat et al. 2018). This is observed to various levels in different Druze communities while changes have occurred over the years.

6 For a more in depth accont of the notion of strong women represented as qawya, however in the Palestinian-Arab society context in Israel, not including the Druze, see Sa'ar (2006).

\section{References}

Abbas, Randa, Sherri P. Pataki, Vered Vaknin-Nusbaum, and Salman Ilaiyan. 2018. What Do They Want from My Life? Parent-Child Relationships as Perceived by Druze Adolescents in Israel. Journal of Adolescent Research 34: 261-81. [CrossRef]

Adwan, Adi. 2013. Arabani. Daliyat al-Karmel: IMDb. Available online: www.imdb.com/title/tt2994212/ (accessed on 20 June 2021).

Alamuddin, Nura S., and Paul D. Starr, eds. 1980. Marriage Contracts and Druze Social Values. In Crucial Bonds Marriage among the Lebanese Druze. New York: Caravan Books, pp. 58-83.

Amer-Alshiek, Jonia, Tahani Alshiek, Yifat Amir Levy, Foad Azem, Ami Amit, and Hadar Amir. 2015. Israeli Druze Women's Sex Preferences When Choosing Obstetricians and Gynecologists. Israel Journal of Health Policy Research 4: 1-10. [CrossRef]

Azzam, Intisar J. 2007. Gender and Religion: Druze Women. London: Druze Heritage Foundation.

Barakat, Ebtesam. 2021. Gender Struggle within Complex Religious Realities: Druze Women in Israel as a Case Study. Gender Issues, 1-25. [CrossRef]

Barakat, Ebtesam, Amal Jamal, and Orna Sasson-Levy. 2018. The Consequences of Blurred Boundaries Between Private And Public Spheres In Patriarchal Societies: Evidence From Druze Women In Israel. Journal of Research in Gender Studies 8: 61-88. [CrossRef]

Beaini, Scarlette. 1989. Something Old, Something New: Marriage Customs among the Druze in the Shouf Mountains of Lebanon. Master's thesis, Portland State University, Portland, OR, USA. Unpublished. Available online: https://pdxscholar.library.pdx. edu/open_access_etds/3873/ (accessed on 20 June 2021).

Ben-Dor, Gabriel. 1976. Intellectuals in Israeli Druze society. Middle Eastern Studies 12: 133-58. [CrossRef]

Bennett, Marjorie Anne. 1999. Reincarnation, Marriage, and Memory: Negotiating Sectarian Identity among the Druze of Syria. Ph.D. dissertation, University of Arizona, Tucson, AZ, USA. Unpublished. Available online: https://repository.arizona.edu/handle/10 150/283987 (accessed on 27 August 2021).

Betts, Robert Brenson. 1988. The Druze. New Haven: Yale University Press.

Blumen, Orna, and Sharon Halevi. 2005. Negotiating National Boundaries: Palestinian And Jewish Women's Studies Students in Israel. Identities 12: 505-38. [CrossRef]

Blumen, Orna, and Shay Tzafrir. 2011. Sentenced to Commute: Indigenous Young Women at a City University. Cultural Analysis 10: 67-89.

Charafeddine, Fahmia. 2010. Predicament of Lebanese Women Married to Non-Lebanese: Field Analytical Study. Al-Raida Journal 1: 19-35. [CrossRef]

Cooke, Miriam. 2012. Nazira Zeineddine: A Pioneer of Islamic Feminism. London: Simon and Schuster.

Dana, Nissim. 2003. The Druze in the Middle East: Their Faith, Leadership, Identity and Status. Brighton and Portland: Sussex Academic Press.

Daoud, Suheir Abu Oksa. 2006. Palestinian Women in the Israeli Knesset. Middle East Report 240: 26-31. [CrossRef]

Dayan, Hava. 2019. Female Honor Killing: The Role of Low Socio-Economic Status and Rapid Modernization. Journal of Interpersonal Violence 36: NP10393-NP10410. [CrossRef]

Di Ricco, Massimo. 2012. Reclaiming Changes within the Community Public Sphere: Druze Women's Activism, Personal Status Law, and the Quest for Lebanese Multiple Citizenship. In Family Law in Islam: Divorce, Marriage and Women in the Muslim World, by Maaike Voorhoeve. Edited by Maaike Voorhoeve. London: I.B. Tauris \& Company, vol. 4, pp. 31-49.

Firro, Kais. 2001. Reshaping Druze Particularism in Israel. Journal of Palestine Studies 30: 40-53. [CrossRef]

Florsheim, Paul, and David Gutmann. 1992. Mourning the Loss of 'Self as Father': A Longitudinal Study of Fatherhood among the Druze. Psychiatry 55: 160-76. [CrossRef] [PubMed]

Fournier, Pascale, Farah Malek-Bakouche, and Eve Laoun. 2018. The State, the Household, and Religious Divorce in Lebanon: Women's Everyday Struggles. In Religion, Gender, and Family Violence: When Prayers Are Not Enough. Edited by Catherine Holtmann and Nancy Nason-Clark. Leiden: Brill, vol. 31, pp. 188-208. [CrossRef] 
Geiger, Brenda. 2013. Female Arab Students' Experience of Acculturation and Cultural Diversity upon Accessing Higher Education in the Northern Galilee-Israel. International Journal of Higher Education 2: 91-106. [CrossRef]

Golan, Moria. 2015. Self-Esteem among Druze Women. Journal of Psychology E Clinical Psychiatry 2: 1-6. [CrossRef]

Goldblatt, Hadass, and Michal Granot. 2006. Domestic Violence Among Druze Women in Israel as Reflected by Health Status and Somatization Level. Women $\mathcal{E}$ Health 42: 19-36. [CrossRef]

Halabi, Abbas. 2013. The Druze: A New Cultural and Historical Appreciation. Reading: Ithaca Press.

Halabi, Rabah. 2014. The Faith, the Honor of Women, the Land: The Druze Women in Israel. Journal of Asian and African Studies 50: 427-44. [CrossRef]

Halabi, Rabah. 2018. The Education System as a Mechanism for Political Control: The Education System for the Druze in Israel. Journal of Asian and African Studies 53: 1018-31. [CrossRef]

Harris, Rachel S. 2013. Parallel Lives: Palestinian, Druze, and Jewish Women in Recent Israeli Cinema on the Conflict: Free Zone, Syrian Bride, and Lemon Tree. Shofar: An Interdisciplinary Journal of Jewish Studies 32: 79-102. [CrossRef]

Hazran, Yusri. 2015. How Elites Can Maintain their Power in the Middle East: The Junblat Family as a Case Study. Middle Eastern Studies 51: 343-69. [CrossRef]

Kastrinou, A. Maria A. 2016. Power, Sect and State in Syria: The Politics of Marriage and Identity amongst the Druze. London: I.B. Tauris.

Katz, Ruth. 1990. Widowhood in a Traditional Segment of Israeli Society: The Case of the Druze War Widow. Plural Societies 20: 13-21.

Kaufman, Iana. 2004. Ethnic affirmation or ethnic manipulation: The case of the Druze in Israel. Nationalism and Ethnic Politics 9: 53-82. [CrossRef]

Khattab, Nabil. 2002. Ethnicity and Female Labour Market Participation: A New Look at the Palestinian Enclave in Israel. Work, Employment and Society 16: 91-110. [CrossRef]

Khoury, Jamilé, and Samantha Wehbi. 2016. Leaving a Violent Domestic Relationship: Experiences of Women in Lebanon. International Social Work 59: 73-85. [CrossRef]

Klat, Myriam, and Adèle Khudr. 1986. Religious Endogamy and Consanguinity in Marriage Patterns in Beirut, Lebanon. Biodemography and Social Biology 33: 138-45. [CrossRef]

Kraus, Vered, and Yuval Yonay. 2013. Ethnicity, Gender, and Exclusion: Which Occupations Are Open to Israeli Palestinian Women? In Palestinians in the Israeli Labor Market: A Multi-Disciplinary Approach, by Nabil Musa. Edited by Nabil Khattab and Sami Miaari. Basingstoke: Palgrave Macmillan, pp. 87-109.

Kraus, Vered, and Yuval Yonay. 2016. Gender Earnings Gaps in Ethnic and Religious Groups in Israel. In Socioeconomic Inequality in Israel: A Theoretical and Empirical Analysis. Edited by Nabil Khattab, Sami Miaari and Haya Stier. Basingstoke: Springer, pp. 185-204.

Kraus, Vered, and Yuval Yonay. 2018. The 'Favorite Minority'?: Druze Women in the Labor Market. In Facing Barriers: Palestinian Women in a Jewish-Dominated Labor Market. Edited by Vered Kraus and Yuval P. Yonay. Cambridge: Cambridge University Press, pp. 178-200.

Layish, Aharon. 1978. The Prohibition of Reinstating a Divorced Wife in the Druze Family. Bulletin of the School of Oriental and African Studies 41: 258-71. [CrossRef]

Layish, Aharon. 1979. Polygamy and the Druze Family in Israel. Journal of the American Oriental Society 99: 58-63. [CrossRef]

Layish, Aharon. 1982. Marriage, Divorce and Succession in the Druze Family. Leiden: E.J. Brill, pp. 55-65.

Mra'ana, Ibtisam. 2008. Lady Kul El Arab. Tel-Aviv: IMDb. Available online: www.imdb.com/title/tt1344850/?ref_=ttpl_pl_tt (accessed on 27 August 2021).

Obeid, Anis. 2006. The Druze and Their Faith in Tawhid. Syracuse: Syracuse University Press.

Offer, Shira, and Michal Sabah. 2011. Individual and Familial Determinants of Married Arab Israeli Women's Labor Force Participation: Trends of Change and Stability. Marriage E Family Review 47: 326-43. [CrossRef]

Oppenheimer, Jonathan W. S. 1980. 'We Are Born in Each Others' Houses': Communal and Patrilineal Ideologies in Druze Village Religion and Social Structure. American Ethnologist 7: 621-36. Available online: www.jstor.org/stable/643473 (accessed on 20 June 2021). [CrossRef]

Prouty, Nada. 2011. Uncompromised: The Rise, Fall, and Redemption of an Arab-American Patriot in the CIA. New York: Macmillan.

Pullum, Lindsey. 2019. A Resolute Display: Culture, Life and Intersectional Identity in Israeli Druze Photography. Anthropology of the Middle East 14: 87-107. [CrossRef]

Radwan, Chad Kassem. 2016. The Sweet Burden: Constructing and Contesting Druze Heritage and Identity in Lebanon. Ph.D. dissertation, The University of South Florida, Tampa, FL, USA. Unpublished. Available online: https://digitalcommons.usf.edu/ etd /6132/ (accessed on 2 September 2021).

Raufman, Ravit. 2018. The Affinity between Incest and Women's Mutilation in the Feminine Druze Versions of 'The Maiden without Hands': An International Motif in a Local Context. Marvels \& Tales 32: 265-95. [CrossRef]

Riklis, Eran. 2004. The Syrian Bride. Tel-Aviv: IMDb. Available online: www.imdb.com/title/tt0423310/?ref_=kw_li_tt (accessed on 27 August 2021).

Rosenfeld, Henry. 1974. Hamula (Concepts and Terms). Journal of Peasant Studies 1: 243-44. [CrossRef]

Sa'ar, Amalia. 2006. Feminine strength: Reflections on power and gender in Israeli-Palestinian culture. Anthropological Quarterly 79: 397-430. [CrossRef] 
Saba-Sa'di, Sylvia, and Ahmad H. Sa'di. 2017. State Power and the Role of Education in the Constitution of Natives' Subjectivities: The Druze in Israel. Social Identities 24: 817-35. [CrossRef]

Sabbah-Karkaby, Maha, and Haya Stier. 2017. Links Between Education and Age at Marriage among Palestinian Women in Israel: Changes Over Time. Studies in Family Planning 48: 23-38. [CrossRef]

Sasson-Levy, Orna. 2017. Ethnicity and Gender in Militaries: An Intersectional Analysis. In The Palgrave International Handbook of Gender and the Military. Edited by Rachel Woodward and Claire Duncanson. London: Palgrave Macmillan, pp. 125-43.

Schnabel, Landon, Conrad Hackett, and David McClendon. 2018. Where Men Appear More Religious Than Women: Turning a Gender Lens on Religion in Israel. Journal for the Scientific Study of Religion 57: 80-94. [CrossRef]

Shamma, Fathi, and Eisam Asaqli. 2020. Gender Differences in Decision-Making During Adolescence: A Comparison of Jewish and Druze Societies. Journal of Educational and Developmental Psychology 10: 65-78. [CrossRef]

Stier, Haya. 2013. Changing Earnings Composition in Israeli-Palestinian Households: The Emergence of the Dual-Earner Family. In Palestinians in the Israeli Labor Market: A Multi-Disciplinary Approach, by Nabil Musa. Edited by Nabil Khattab and Sami Miaari. Basingstoke: Palgrave Macmillan, pp. 111-30.

Swayd, Samy. 2009. The A to Z of the Druzes. The A to Z Guide Series; Lanham: Scarecrow Press, vol. 53.

Tarabey, Lubna. 2013. Family Law in Lebanon: Marriage and Divorce among the Druze. London: Bloomsbury Publishing, pp. 175-95.

Vardi-Saliternik, R., Yechiel Friedlander, and Ted Cohen. 2002. Consanguinity in a Population Sample of Israeli Muslim Arabs, Christian Arabs and Druze. Annals of Human Biology 29: 422-31. [CrossRef]

Weiner-Levy, Naomi. 2008a. On Cross-Cultural Bridges and Gaps: Identity Transitions among Trailblazing Druze Women. Gender and Education 20: 137-52. [CrossRef]

Weiner-Levy, Naomi. 2008b. When the Hegemony Studies the Minority-An Israeli Jewish Researcher Studies Druze Women. Qualitative Inquiry 15: 721-39. [CrossRef]

Weiner-Levy, Naomi. 2009. ‘ . . But It Has Its Price': Cycles of Alienation and Exclusion among Pioneering Druze Women. International Journal of Educational Development 29: 46-55. [CrossRef]

Weiner-Levy, Naomi. 2011. Patriarchs or Feminists? Relations Between Fathers and Trailblazing Daughters in Druze Society. Journal of Family Communication 11: 126-47. [CrossRef]

Xiao, Yu, and Maria Watson. 2019. Guidance on Conducting a Systematic Literature Review. Journal of Planning Education and Research 39: 93-112. [CrossRef]

Yefet, Karin Carmit. 2015. Feminism and Hyper-Masculinity in Israel: A Case Study in Deconstructing Legal Fatherhood. Yale JL E Feminism 27: 47-94.

Yehya, Nadine A., and Mohan J. Dutta. 2010. Health, Religion, and Meaning: A Culture-Centered Study of Druze Women. Qualitative Health Research 20: 845-58. [CrossRef] [PubMed]

Yonay, Yuval P., Meir Yaish, and Vered Kraus. 2014. Religious Heterogeneity and Cultural Diffusion: The Impact of Christian Neighbors on Muslim and Druze Women's Participation in the Labor Force in Israel. Sociology 49: 660-78. [CrossRef]

Zaatut, Amarat, and Muhammad M Haj-Yahia. 2016. Beliefs about Wife Beating among Palestinian Women from Israel: The Effect of Their Endorsement of Patriarchal Ideology. Feminism \& Psychology 26: 405-25. [CrossRef]

Zeedan, Rami. 2019. The Role of Military Service in the Integration/Segregation of Muslims, Christians and Druze within Israel. Societies 9: 1. [CrossRef]

Zuhur, Sherifa. 2000. Asmahan's Secrets: Woman, War, and Song. Austin: University of Texas Press, vol. 13. 